\title{
História de uma experiência de ensino: o caso da disciplina Conceitos de
} Física $D$ da UFBA ${ }^{+}$

\author{
José Fernando Moura Rocha ${ }^{1}$ \\ Instituto de Física - Universidade Federal da Bahia \\ Salvador - BA
}

\section{Resumo}

Neste trabalho, analisa-se historicamente a experiência de ensino, realizada no Curso de Física, da Universidade Federal da Bahia (UFBA), envolvendo a disciplina Conceitos de Física D, anteriormente denominado Física Básica IV, que tem a óptica e elementos de física moderna como seu conteúdo programático. Tal experiência, iniciada em 1999, se constitui em um exemplo de incorporação da história da ciência ao ensino de ciências ou, mais especificamente, ao ensino da física universitária básica. Inicialmente, são discutidas as principais dificuldades encontradas pelos professores para ministrar essa disciplina e também como as mesmas foram enfrentadas, ao longo do tempo, inclusive com a produção de material didático; em seguida, será discutida a forma como o seu conteúdo programático foi efetivamente trabalhado em sala de aula, isto é, como as atividades foram realizadas, qual o material usado e como os alunos interagiram com esse material. Finalmente, será apresentada a visão dos alunos sobre a abordagem utilizada na mencionada disciplina.

Palavras-chave: Ensino de Física; História da Física; Óptica; Física Moderna.

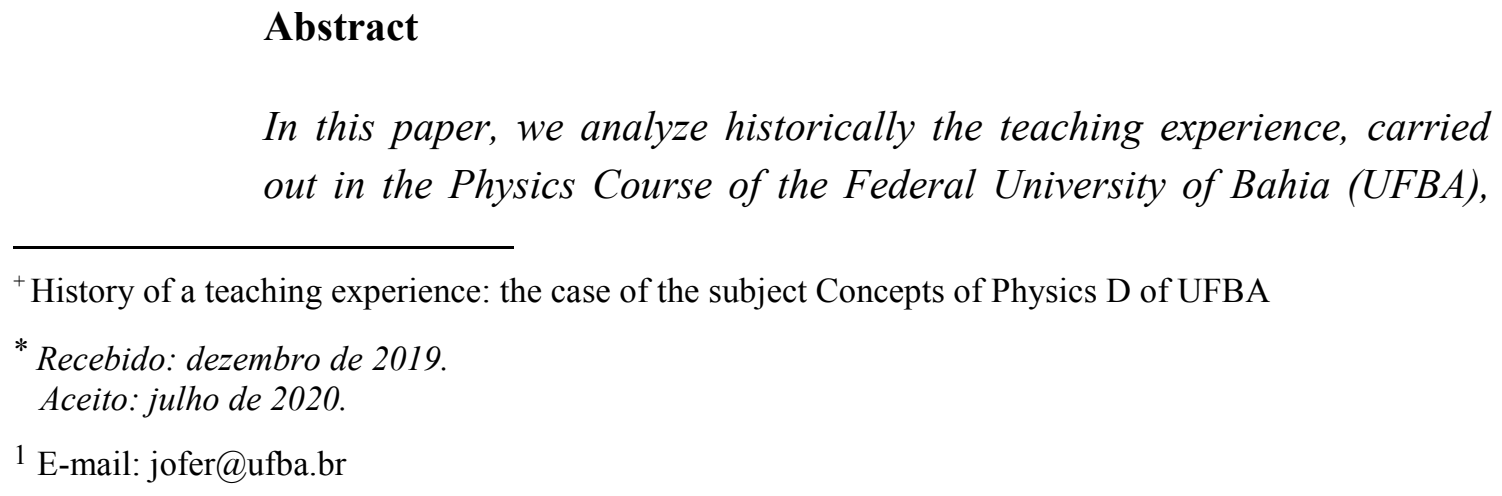

In this paper, we analyze historically the teaching experience, carried out in the Physics Course of the Federal University of Bahia (UFBA),

\footnotetext{
${ }^{+}$History of a teaching experience: the case of the subject Concepts of Physics D of UFBA

* Recebido: dezembro de 2019. Aceito: julho de 2020.

${ }^{1}$ E-mail: jofer@ufba.br
} 
involving the curricular component Concepts of Physics D, called previously Basic Physics IV, which has optics and elements of modern physics as its syllabus. This experience, which began in 1999, constitutes an example of incorporating the history of science into science teaching or, more specifically, to the teaching basic university physics. Initially, we discussed the main difficulties encountered by teachers to teach this curricular component and also how they were faced, over time; and then discuss how their programmatic content was effectively worked in the classroom, ie how the activities were carried out, what material was used and how the students interacted with that content material. Finally, we present the view of the students about the approach used in the mentioned curricular component.

Keywords: Physics Teaching; History of Physics; Optics; Modern Physics.

\section{Introdução}

Neste trabalho, analisa-se historicamente a experiência de ensino na disciplina Conceitos de Física D, anteriormente denominada Física Básica IV, do Curso de Física da Universidade Federal da Bahia (UFBA), que tem a óptica e elementos de física moderna como conteúdo programático. Tal experiência se constitui em um exemplo de incorporação da história da ciência ao ensino de ciências ou, mais especificamente, ao ensino da física universitária básica. A disciplina Conceitos de Física $D$, ou melhor, as disciplinas Conceitos de Física $A, B, C$ e $D$ são integrantes do atual Projeto Pedagógico do Curso de Física, implantado em 2016, e eram, anteriormente, denominadas Físicas Básicas I, II, III e IV². Essas disciplinas foram criadas, em 1998, como parte do Projeto Pedagógico do Curso de Física, Licenciatura, noturno, da UFBA, e eram consideradas uma das inovações importantes trazidas pela sua matriz curricular. Com a extensão do chamado projeto das Físicas Básicas ao Curso de Física, diurno (licenciatura e bacharelado), a partir de 2016, essas disciplinas passaram a ser oferecidas não mais apenas para alunos do Curso de Física, Licenciatura, noturno, como acontecia desde a criação, mas também para alunos do Curso de Física, diurno, o que ocorre paralelamente aos cursos tradicionais de Física Geral e Experimental I, II, III e IV, destinados aos alunos da chamada área de ciências exatas, inclusive aos alunos de licenciatura e bacharelado em Física.

\footnotetext{
2 As disciplinas Físicas Básicas I, II, III e IV não devem ser associadas aos livros didáticos do professor H. Moysés Nussenzveig intitulados "Curso de Física Básica" (v. 1, 2, 3 e 4), nem identificadas com as tradicionais Físicas Gerais e Experimentais.
} 
Dois anos antes da extensão dessas disciplinas ao Curso de Física, diurno, uma análise da repercussão das inovações trazidas pela matriz curricular do Curso de Física, Licenciatura, noturno, em particular aquelas expressas pelas disciplinas Físicas Básicas I, II, III e IV, na formação acadêmica dos alunos, foi realizada pelo autor deste trabalho, em tese de doutorado, defendida em 2014. Parte de tal análise foi apresentada nos artigos "História de uma experiência singular de ensino - Parte I: a criação do Curso de Física, Licenciatura, noturno, da UFBA" e "História de uma experiência singular de ensino - Parte II: o caso das disciplinas Físicas Básicas”, publicados em $2016^{3}$. Na citada Parte II, foi apresentada também uma discussão específica do processo de implantação das disciplinas Físicas Básica I e II, inclusive a receptividade dos alunos à abordagem utilizada. À época, a discussão do processo de implantação e desenvolvimento das disciplinas Físicas Básicas III e IV e as opiniões avaliativas dos alunos sobre a abordagem dos conteúdos utilizada nessas disciplinas foram deixadas para serem tratadas em artigos posteriores, em razão do volume de informações disponíveis a respeito das mesmas, promessa essa que está sendo cumprida neste momento. Como o volume de informações referentes a cada uma dessas disciplinas, em separado, também era grande, optamos por desdobrar tal discussão em dois artigos independentes: um deles, o presente trabalho, visando a analisar historicamente a experiência de ensino da disciplina Física Básica IV (ver ementa na Fig. 1a), atualmente denominada Conceitos de Física $D$ (ver ementa na Fig. 1b); e o outro, a ser redigido posteriormente, visando a analisar historicamente a experiência de ensino da disciplina Física Básica III, atualmente denominada Conceitos de Física $C$.

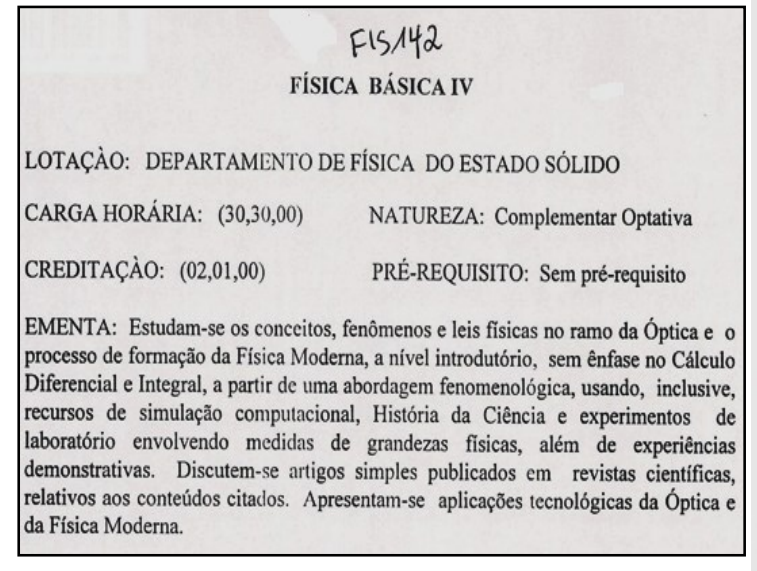

Fig.la - Ementa da disciplina Física Básica IV. Fonte: IFUFBA, Colegiado de Graduação em Física, 1998.

\begin{tabular}{|c|c|c|c|}
\hline $\begin{array}{l}\text { Código e Nome do Componente Curricular: } \\
\text { FISFH4 - Conceitos de Fisica D }\end{array}$ & $\begin{array}{l}\text { Departamento: } \\
\text { FIS05 - Estado Sólido }\end{array}$ & $\begin{array}{l}\text { Carga Horária: } \\
\text { Total:68h } \\
\text { T: 34h P: 34h E: } 0\end{array}$ & \\
\hline $\begin{array}{l}\text { Modalidade: } \\
\text { Disciplina }\end{array}$ & $\begin{array}{l}\text { Funcio: } \\
\text { Profissional }\end{array}$ & $\begin{array}{l}\text { Natureza: } \\
\text { Bacharelado: } \\
\text { Optativa }\end{array}$ & \begin{tabular}{|l} 
Licenciatura: \\
Optativa
\end{tabular} \\
\hline $\begin{array}{l}\text { Prérequisito: } \\
\text { Conceitos de Fisica C(FISf03) } \\
\end{array}$ & & $\begin{array}{l}\text { Modulo de alunos: } \\
\text { T: } 30 \mathrm{P}: 15 \mathrm{E}: 00 \\
\end{array}$ & \\
\hline \multicolumn{4}{|c|}{ 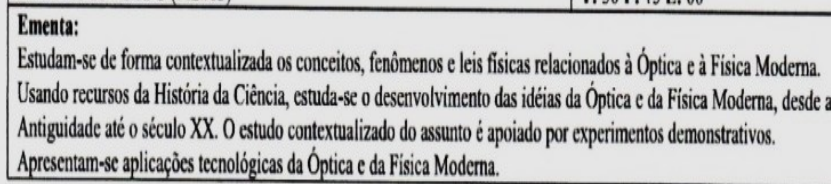 } \\
\hline
\end{tabular}

Fig.1b - Ementa da disciplina Conceitos de Física D. Fonte: IFUFBA, Colegiado de Graduação em Física, 2016.

\footnotetext{
3 "História de uma experiência singular de ensino - Parte I: a criação do Curso de Física, Licenciatura, noturno, da UFBA"; e "História de uma experiência singular de ensino Parte II: o caso das disciplinas Físicas Básicas", publicados no Caderno Brasileiro de Ensino de Física, em 2016 (vol. 33, números 1 e 2, respectivamente).
} 
No que diz respeito aos objetivos e natureza curricular da disciplina Física Básica IV, devemos dizer, inicialmente, que desde a criação do chamado projeto das Físicas Básicas, em 1998, o objetivo dessa disciplina (agora com a denominação Conceitos de Física $D$ ) tem sido o de apresentar um curso universitário básico de óptica e elementos de física moderna para alunos da física, através de uma abordagem contextual, simultaneamente histórica, fenomenológica (experimental), matemática e conceitual. No que diz respeito à sua parte prática, essa é largamente suportada por quase uma centena de experimentos simples, demonstrativos (não só qualitativos), diretamente relacionados com o nosso cotidiano ou possíveis de serem relacionados com este, e que, em cada aula (na maioria delas), servem de motivação para a subsequente e imediata discussão teórica de conceitos da física clássica ou de física moderna, a elas relacionados, inclusive nos seus aspectos matemáticos mais simples. As discussões, na sua maior parte, desde o início do curso, são orientadas para o confronto dos modelos de onda e partícula de luz.

É oportuno esclarecer que, na estrutura curricular do Curso de Física, Licenciatura, noturno, as disciplinas Física Básica III e IV foram incluídas, em 1998, como optativas , e isso ocorreu em razão de uma série de fatores conjunturais, de natureza acadêmica, a exemplo da forte recomendação da Pró-Reitoria de Graduação da UFBA para que as novas propostas de currículo tivessem o menor número possível de disciplinas obrigatórias. Essa insistência da Pró-Reitoria de Graduação era decorrente de discussões que estavam acontecendo nacionalmente, inclusive na UFBA, com o objetivo de promover a renovação dos currículos das licenciaturas. Para os organizadores do curso noturno, entretanto, não era relevante se esses componentes curriculares deveriam ser obrigatórios ou optativos, já que, de qualquer modo, teriam de ser regularmente oferecidos, diante da pouca oferta de disciplinas por outras Unidades da UFBA, no período da noite, e também por não haver perspectiva de criação imediata de outros cursos noturnos, na UFBA 5 .

A análise histórica da experiência de ensino da disciplina Conceito de Física $D$, referente ao período de 2000 a 2014 (quando então era denominada Física Básica IV), apresentada neste artigo, terá como referência principal o trabalho de doutorado de Rocha (2014), o qual foi realizado com base em documentos obtidos nos arquivos do Instituto de Física da UFBA, em especial, aqueles do Colegiado do Curso de Física e do Departamento de Física do Estado Sólido, e também nos arquivos pessoais do professor que ministrou essa disciplina o maior número de vezes. Neles, estavam disponíveis, entre outros documentos, notas de aula, os chamados textos complementares produzidos pelo docente e também livros e

\footnotetext{
${ }^{4}$ No Projeto Pedagógico do Curso de Física, implantado em 2016, as disciplinas Conceitos de Física $A, B$ e $C$ são obrigatórias e apenas a disciplina Conceitos de Física $D$ permaneceu optativa, mas todas têm sido oferecidas regularmente, uma vez por ano.

5 Em razão da pouca oferta de disciplinas optativas no período da noite, as disciplinas Física Básica III e IV, eram muito concorridas para os padrões de uma disciplina optativa de física. A média de alunos matriculados na disciplina Física Básica III, ao longo dos primeiros 13 anos, foi de 22 alunos/turma, e na disciplina Física Básica IV, ao longo de 12 anos, foi de 15 alunos/turma (ROCHA, 2014). Nos primeiros 8 anos de funcionamento, o Curso de Física, Licenciatura, noturno, era o único curso oferecido inteiramente à noite.
} 
artigos utilizados para redigi-los. No que se refere, especificamente, à avaliação da abordagem utilizada na disciplina Física Básica IV, esta foi realizada, de acordo com Rocha, no contexto do estudo da repercussão, entre discentes e docentes, das inovações trazidas não apenas pela disciplina Física Básica IV, mas pela própria matriz curricular do Curso de Física, Licenciatura, noturno, em particular, pelas inovações introduzidas pelas disciplinas Físicas Básicas I, II, III e IV. Naquela oportunidade, em razão do número reduzido de fontes documentais disponíveis sobre tal repercussão, o principal recurso utilizado por Rocha foi o da metodologia da história oral e, no caso de Física Básica IV, além dos dados obtidos através da metodologia da história oral, foram obtidos dados também através de alguns documentos (questionários abertos aplicados) existentes nos arquivos pessoais do professor .

No que segue, a exposição será dividida em quatro partes principais: primeiro, serão discutidas as principais dificuldades encontradas pelos professores para ministrar essa disciplina e como tais dificuldades foram enfrentadas, ao longo do tempo, inclusive com a produção de material didático; em seguida, será discutida a forma como o seu conteúdo programático foi efetivamente trabalhado em sala de aula, isto é, como foram realizadas as atividades, qual o material usado e como os alunos interagiram com esse material. Finalmente, será apresentada a visão dos alunos sobre a abordagem utilizada na disciplina.

\section{As dificuldades de implantação}

De acordo com Rocha (2014, p. 167) a disciplina Física Básica IV (atualmente denominada Conceitos de Física $D$ ) foi oferecida pela primeira vez no segundo semestre do ano 2000. Dois professores dividiram a responsabilidade de ministrar essa disciplina, tendo um deles ficado responsável pela parte de óptica e o outro pela parte de física moderna, mas ambos concordando com a abordagem a ser adotada, isto é, uma abordagem contextual, com a história da ciência sendo usada para estruturar o próprio curso, e não como um tópico especial introduzido em um ou outro ponto específico de uma programação tradicional de ensino de ciência. Tal divisão de responsabilidades ocorreu somente nos dois primeiros semestres em que a disciplina foi oferecida, sendo que nos demais semestres a mesma ficou a cargo de apenas um professor.

Na primeira parte do curso, ou seja, na parte de óptica clássica, foram estudados os fenômenos básicos de reflexão, refração, interferência, difração e polarização, com experimentos de laboratório ocupando metade da carga horária disponível, sendo que, na segunda parte, que envolvia elementos de física moderna, foi utilizado o material produzido pela professora Ileana Maria Rosa Greca, aplicado em um curso por ela ministrado na Universidade Federal do Rio Grande do Sul, destinado a alunos de Física Geral, como parte

\footnotetext{
6 A repercussão da extensão das disciplinas Físicas Básicas para o curso diurno, implantadas partir do ano de 2016, está sendo objeto de análise, no momento, em trabalho desenvolvido por um aluno do Programa Pós-Graduação em Ensino, Filosofia e História da Ciência, da UFBA.
} 
dos requisitos para a obtenção do título de doutora em ciências ${ }^{7}$, material esse que foi utilizado apenas nos semestres 2000.2 e 2001.2.

As principais dificuldades enfrentadas, à época, pelos professores, para a implantação da disciplina Física Básicas IV podem ser resumidas, ainda de acordo com Rocha (2014, p. 168), nos seguintes pontos: 1) a escolha do livro-texto; 2) o tempo disponível para a preparação de textos/notas de aula que servissem de referências para os alunos; 3) a seleção de assuntos que pudessem ser tratados sem sofisticação matemática, mas com linguagem ou enfoque de nível superior; 4) a identificação de experimentos de laboratório que pudessem ser apresentados, ao mesmo tempo que a parte teórica da disciplina e que fossem diferentes daqueles já oferecidos nas Físicas Gerais e Experimentais, considerando-se os equipamentos disponíveis; 5) a preparação de listas de exercícios, apropriada para aquele tipo de curso; e 6) a inexistência de uma sala de laboratório específica para a disciplina, com equipamentos adequados para experimentos demonstrativos (não só qualitativos). Evidentemente que, com tais dificuldades, o rendimento dessa disciplina (e das demais Físicas Básicas) ficava a depender, sobretudo, do desempenho do professor.

No que diz respeito ao item 1, isto é, ao problema da escolha do livro-texto, podemos afirmar que a origem dessa dificuldade estava, principalmente, no fato de que o propósito dos docentes designados para ministrar a disciplina era o de estruturar o curso em bases históricas, incluindo, extensivamente, o conteúdo de História da Ciência (História da Física). Naturalmente, essa opção exigiria um bom livro de texto, ou a preparação prévia de textos/notas de aula para orientar as discussões em sala de aula, tendo em vista que sem esse material o curso poderia adquirir uma característica predominantemente fenomenológica. Para a primeira parte do curso, que tratava da óptica, essa dificuldade foi contornada, parcialmente, recomendando-se o livro Projecto Física - Luz e Eletromagnetismo, Unidade $4^{8}$, mesmo sem a coleção dos textos adicionais, denominada "Coletânea de Textos", que só estava disponível em língua inglesa. Dissemos que essa recomendação se apresentou como solução parcial, em razão de o livro não ser destinado a alunos da área de ciências, de nível superior. Apesar do Projecto Física já incluir também sugestões de experimentos de óptica, foi recomendado, à época, também o livro Física Térmica e Óptica, do Grupo de Reelaboração do Ensino de Física - GREF, volume 2 ("textos para professores") ${ }^{9}$, mesmo não havendo nele referência alguma ao desenvolvimento histórico das ideias da óptica e de física moderna. Outros textos,

\footnotetext{
${ }^{7}$ GRECA, I. M. R. Construindo significados em Mecânica Quântica: resultados de uma proposta didática aplicada a estudantes de Física Geral. 2000. Tese (Doutorado) - Programa de Pós-Graduação em Física, Universidade Federal do Rio Grande do Sul, Porto Alegre.

8 HOLTON, G.; RUTHERFORD, F. J.; WATSON, F. G. Projecto Física - Luz e Eletromagnetismo, Unidade 4. Lisboa: Fundação Calouste Gulbenkian, 1985.

${ }^{9}$ Grupo de Reelaboração do Ensino de Física - GREF. Física 2 - Física Térmica e Óptica. São Paulo: Edusp, 1993.
} 
como o livro intitulado Física, de Paul Tipler, e o livro Física, de Jay Orear (volume único) ${ }^{10}$, também recomendados, não se constituíram igualmente soluções adequadas e, dessa forma, a questão da escolha do livro-texto, para essa parte do curso (óptica), não foi satisfatoriamente resolvida. No que se refere à segunda parte, isto é, elementos de física moderna, utilizou-se o texto produzido pela professora Ileana Greca, citado anteriormente, mas alguns alunos não se adaptaram plenamente àquela proposta de curso, conforme veremos mais adiante. Sendo assim, o problema de um livro-texto específico foi contornado apenas parcialmente, seja para a parte de óptica, seja para a de física moderna, reforçando a necessidade citada no item 2, de produção de textos próprios para as disciplinas Físicas Básicas, do Curso de Física, Licenciatura, noturno, o que se mostrou a parte mais difícil de ser equacionada, pois, na prática, só poderia ser resolvida a médio prazo, assunto a respeito do qual voltaremos a falar na próxima seção. A ideia de compensar a falta de um livro-texto específico por artigos diversos não foi considerada, explicitamente, sendo a eventual utilização de artigos, em sala, considerada apenas como uma atividade de caráter complementar (conforme indicado na própria ementa da disciplina), uma ideia que, no caso de Física Básica IV, não foi efetivamente exercitada. Artigos foram consultados, entretanto, como fonte de informação para a preparação dos chamados textos complementares.

No que se refere ao item 3, isto é, à seleção de assuntos que pudessem ser tratados em Física Básica IV sem sofísticação matemática, mas com linguagem ou enfoque de nível superior, pode-se afirmar que a dificuldade não era, propriamente, a de selecionar uma sequência de tópicos clássicos da óptica (fenômenos de propagação retilínea, reflexão, refração, difração, interferência, polarização etc.) a serem abordados, mas tópicos que pudessem ser suportados por experimentos demonstrativos de importância histórica e conceitual e para os quais houvesse equipamentos disponíveis. Essa dificuldade ocorreu também no item 4, ao se tentar identificar experimentos, tendo em conta os equipamentos disponíveis (dentre eles, alguns da própria disciplina Física Geral e Experimental IV), uma dificuldade que, nos dois semestres iniciais, foi superada, tanto quanto possível, em razão da experiência do docente no ensino da óptica universitária básica, que lhe permitia realizar adaptações e improvisações. Ao longo do tempo, entretanto, algum progresso foi conseguido, mesmo sem recursos financeiros específicos, e, para a parte do curso referente à óptica, alguns dispositivos ou materiais simples foram sendo improvisados (com custo insignificante) e outros equipamentos (de custo não tão insignificante) foram sendo agregados, como os novos interferômetros de Michelson, as novas fontes de laser e, para o estudo da refração, peças de acrílico e de vidro, em forma de semicírculo. No que se refere à parte de física moderna, alguns equipamentos, localizados no laboratório de Estrutura da Matéria, passaram a ser utilizados para o estudo do efeito fotoelétrico, mesmo com alguns deles, à época, já danificados parcialmente. Ainda com relação ao item 4, pode-se dizer que os experimentos

\footnotetext{
10 TIPLER, P. Física. 2. ed. Rio de Janeiro: Editora Guanabara Dois S. A., 1984. v. 2b; OREAR, J. Física. Rio de Janeiro: Livros Técnicos e Científicos Editora Ltda., 1971.
} 
propostos pelo citado Projecto Física (ou Harvard Project Physics) assim como aqueles propostos pelo Grupo de Reelaboração do Ensino de Física não eram em número suficiente ou adequados para cobrir toda a parte experimental de Física Básica IV, considerando a forma como essa foi concebida.

Sobre o item 5, é necessário, mais uma vez, separar a parte de óptica da parte de física moderna. Na parte de óptica, a alternativa foi usar exercícios do próprio Projecto Física (que se mostraram, entretanto, muito simples) e de outros livros, além da elaboração de algumas questões conceituais relacionadas aos temas discutidos em sala de aula. No que se refere à parte de física moderna, o próprio material produzido pela professora Ileana Greca já continha os exercícios.

Finalmente, sobre a inexistência de salas de laboratório/teoria específicas para essa disciplina, com equipamentos adequados para aulas demonstrativas (não só qualitativos), pode-se dizer que, na parte de óptica, esse problema foi contornado com a utilização das salas destinadas ao laboratório de Física Geral e Experimental IV, com capacidade para até 20 alunos.

Esse foi, portanto, o relato histórico das dificuldades encontradas durante a implantação da disciplina Física Básica IV. É importante registrar que, nos semestres que se seguiram, houve algum progresso nas condições de ensino, especialmente no que se refere aos recursos didáticos.

\section{A produção de material didático}

O problema da carência de textos de natureza histórico-conceitual específicos para esta disciplina (que se relacionassem diretamente com a parte experimental apresentada em sala de aula) foi, como já referido, uma dificuldade enfrentada desde o primeiro semestre em que essa foi oferecida. Aos poucos, entretanto, ao longo do semestre 2000.2 e dos semestres seguintes, algum material didático foi sendo produzido e, de alguma forma, utilizado em sala de aula. A esse respeito, pode-se identificar dois tipos de material: i) os textos, classificados aqui como complementares, e ii) as publicações selecionadas, isto é, livros ou capítulos de livro selecionados. Os "Textos Complementares", em número maior que uma dezena, constituíram, posteriormente, o Apêndice 4 da tese de doutorado de Rocha (2014), e serão objeto de discussão mais adiante. No que diz respeito às publicações selecionadas, Pode-se destacar, inicialmente, o livro Origens e Evolução das Ideias da Física, publicado em $1^{\mathrm{a}}$ edição, em 2002, e, em $2^{\mathrm{a}}$ edição, em $2015^{11}$, ainda que não produzido inicialmente com essa finalidade. Desse livro, três capítulos foram recomendados aos alunos. Um deles foi o capítulo III, intitulado Origem e Evolução do Eletromagnetismo, especialmente a parte que tratava dos aspectos histórico-conceituais da óptica, que, como se sabe, foi incorporada à Teoria Eletromagnética clássica, no século XIX, através dos trabalhos de Maxwell e outros. Além do

${ }^{11}$ ROCHA, J. F. M. (Org.) et al. Origens e Evolução das Ideias da Física. 2. ed. Salvador: EDUFBA, 2015. 
capítulo III, foram recomendados também os capítulos IV (Novo tempo, novo espaço, novo espaço-tempo: Breve história da Relatividade) e V (Os Quanta e a Física Moderna), de autoria de O. Freire Júnior e A. Ribeiro Filho, respectivamente.

Um outro trabalho também relacionado à disciplina Física Básica IV e à física moderna, de nossa autoria, intitulado $O$ conceito de 'dualidade onda-partícula' em sala de aula, foi produzido e pode ser encontrado no Anexo 2 da tese de doutorado de Rocha (2014, p. 517). Esse trabalho é, em linhas gerais, uma breve revisão histórica do desenvolvimento da óptica desde a antiguidade até o nascimento da física moderna, no início do século XX.

Após esses comentários sobre a apresentação do material didático, passaremos a apresentar a forma como foi efetivamente trabalhado em sala de aula o conteúdo programático dessa disciplina e, na seção seguinte, as opiniões dos alunos sobre a abordagem utilizada.

\section{A abordagem do conteúdo}

Esta seção será dividida em duas partes. Na primeira, será apresentada a dinâmica do curso desenvolvida em sala de aula, antecedida da relação dos recursos didáticos utilizados. Na segunda, será realizada a apresentação do conteúdo programático propriamente dito.

\section{IV.1 A dinâmica do curso e os recursos didáticos utilizados}

A discussão apresentada aqui, como anunciado anteriormente, é baseada, essencialmente, em Rocha (2014), onde pode ser encontrado o relato histórico da experiência de ensino vivida pelo professor dessa disciplina, ao longo de mais de uma década, a partir de 2000, ministrando-a sozinho ou, nos primeiros dois semestres em que foi oferecida, em parceria com um colega. No citado trabalho, dentre outros materiais utilizados no curso, o autor fala das notas de aula distribuídas em sala (parte experimental e teórica), dos slides utilizados, dos textos complementares - escritos numa perspectiva internalista e preparados não em um único semestre, mas ao longo dos primeiros anos em que a disciplina foi oferecida - dos artigos e livros consultados, e das experiências demonstrativas realizadas (não só qualitativas). Com o intuito de complementar o relato de Rocha, serão acrescentadas, a seguir, algumas informações sobre a dinâmica desenvolvida em sala de aula.

Inicialmente, deve ser esclarecido que a dinâmica desenvolvida em sala de aula tinha o propósito de valorizar a participação dos alunos e foi determinada, preliminarmente, pela opção do professor de, sempre que possível, apresentar, logo no início de cada aula, os experimentos demonstrativos, seguidas das discussões histórico-matemático-conceituais. Tais experimentos eram descritos, resumidamente, nas notas de aula da parte experimental, entregues pelo professor aos alunos, como roteiro, imediatamente antes da apresentação dos experimentos. O número de experimentos demonstrativos (não só qualitativos) variava de acordo com o tema da aula, com os alunos posicionados em torno de bancadas, onde se encontravam os diferentes experimentos demonstrativos, preparados, antecipadamente, pelo 
professor (o tempo médio de preparação era de uma hora). Iniciada a apresentação do experimento, a participação ativa dos alunos era estimulada pela problematização de cada assunto, através de questões direcionadas pelo professor aos alunos e de questões formuladas pelos próprios alunos a seus colegas e ao professor, com o intuito de esclarecer aspectos essenciais do fenômeno que estava sendo observado. Quando o número de experimentos demonstrativos era muito grande, as discussões de caráter histórico (com a ajuda slides) eram levadas para a aula seguinte, e, quando o número não era grande, tais discussões eram realizadas na mesma aula da apresentação dos experimentos, o que acontecia com maior frequência. É necessário registrar que, mesmo depois de produzidos os textos complementares, a atenção dos alunos do curso noturno ficava voltada, normalmente, para as notas de aula extraídas de tais textos (acrescidas, eventualmente, de lista de exercício). Os alunos do curso noturno geralmente não colocavam em primeiro plano a consulta à bibliografia apresentada no "plano de curso", nem a consulta aos textos complementares já referidos, seja por falta de tempo para leitura, seja pelo fato de considerarem (erroneamente) que a falta de leitura de tais textos seria compensada pelas notas de aula e discussões realizadas em sala, ou mesmo por falta de empenho do professor.

A avaliação da aprendizagem do conteúdo assim apresentado, em cada uma das duas unidades do curso, era realizada através de verificação individual (prova escrita), envolvendo, principalmente, questões de caráter histórico-conceitual, às vezes, experimental e, raramente, matemático. A cada aluno, era também atribuída uma terceira nota/conceito referente à sua participação nas aulas (inclusive sua frequência).

Nas condições oferecidas para a disciplina ser ministrada, cada turma não podia ter mais de vinte alunos, pois essa era a capacidade máxima da sala de aula teórica-experimental utilizada.

Após essas considerações, vejamos, em detalhes, o conteúdo discutido ao longo do curso.

\section{IV.2 O conteúdo abordado}

Ao elaborar o "plano de curso" da disciplina Física Básica IV, cujo conteúdo envolvia elementos de óptica e física moderna, partiu-se do pressuposto que as conceituações e proposições mais gerais devem ser apresentadas no início de qualquer processo de instrução. Com base nesse pressuposto, a orientação do curso foi dirigida para o problema da natureza da luz, um problema sempre presente nas reflexões de filósofos e cientistas, ao longo de séculos. A escolha desse tema geral visava a provocar o interesse dos alunos para o estudo dos fenômenos de reflexão, refração, interferência, difração, polarização, entre outros, o que era feito sempre com base nos modelos corpuscular e ondulatório da luz.

Com o propósito de adotar uma abordagem simultaneamente histórica, fenomenológica, matemática e conceitual, a apresentação do problema da natureza ou constituição da luz, no início do curso, era feita através de um procedimento que poderia ser 
considerado inovador. Para iniciar, eram realizados dois sugestivos experimentos com luz (Fig. 2), que, eventualmente, exigiriam explicações aparentemente contraditórias. De um lado, o experimento da câmara escura de orifício, em que a imagem de uma vela aparecia invertida e, de outro, um experimento de difração, em que um padrão de difração (interferência) era formado num anteparo, após um feixe de luz laser incidir num orifício circular ou numa fenda estreita retangular.

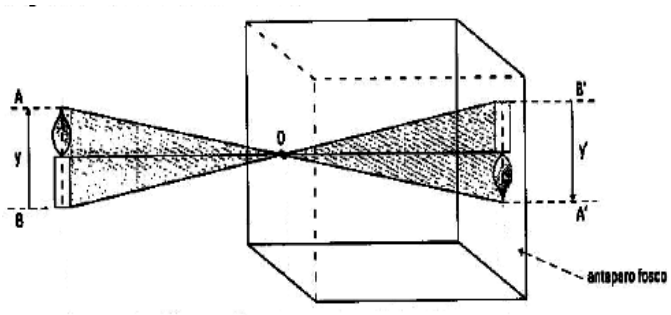

a)

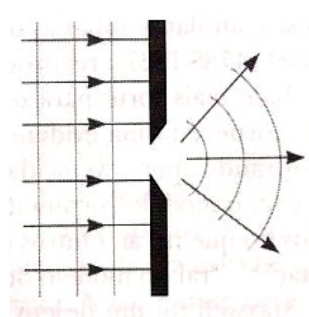

b)

Fig. 2 - Representação esquemática a) do experimento da câmara escura e b) do experimento de difração por uma fenda.

Ao serem solicitados a explicar e comparar as explicações teóricas do que era observado nesses experimentos, geralmente, os alunos se defrontavam com um aparente paradoxo: se para explicar a imagem invertida da chama de uma vela na câmara escura, eles usavam o "princípio de propagação retilínea". o mesmo não era feito para explicar as franjas claras e escuras que apareciam no anteparo, no caso do experimento com a luz de uma fonte de laser. Essas sutilezas do comportamento da luz, explicadas classicamente por Augustin Fresnel, nas primeiras décadas do século XIX, serviam de motivação para se introduzir o problema da natureza da luz.

Após as discussões desses dois experimentos era enfatizado pelo professor que a óptica geométrica (que é, essencialmente, um modelo de partícula) é um conjunto de fenômenos em situações nas quais os efeitos de interferência e de difração são desprezíveis, isto é, em situações em que o aspecto de onda da radiação luminosa não é relevante. Em tais situações, o chamado comprimento de onda $(\lambda)$ da luz, é muito menor que as dimensões típicas $(d)$ envolvidas na propagação da onda (dimensões de obstáculos e orifícios).

A discussão precedente era então ampliada, cogitando-se sobre o que ocorreria em cada uma dessas experiências na hipótese da intensidade do feixe de luz ser suficientemente fraco a ponto de chegar ao anteparo uma partícula de luz de cada vez (regime chamado quântico). Apresentado dessa forma, o problema da natureza da luz, na perspectiva do professor, ficava bem estabelecido e, ao longo do curso, era constantemente retomado e aprofundado. Tais experimentos e discussões eram importantes, porque, mais adiante, mostrava-se que a mecânica clássica podia ser considerada também um caso especial da mecânica ondulatória de Schrödinger, isto é, que a mecânica clássica descreve situações em 
que o chamado comprimento de onda de L. de Broglie, é muito menor que as dimensões típicas envolvidas na propagação da onda de matéria.

$\mathrm{Na}$ sequência imediata, abordava-se o problema da natureza da luz de um outro ponto de vista, ou seja, de um ponto de vista puramente teórico, e com base em ideias da física moderna. Apresentava-se então o postulado de Planck, $E=h f$, no seu conteúdo mais simples, mostrando-se que esse postulado, se tratado do ponto de vista clássico, contém internamente um "absurdo", desde quando, do lado esquerdo desta equação, $E$ refere-se à energia de uma partícula que, supostamente, é algo de pequena extensão, ou pontual, enquanto que, do lado direito da equação, $f$ refere-se à frequência de uma onda que, supostamente, ocupa uma larga extensão do espaço! O problema, naturalmente, era o de como superar esse conflito. O professor então esclarecia que a discussão desse conflito seria retomada na parte final do curso e aproveitava para explicar, sinteticamente, que o caminho seguido foi o de abandonar, a contragosto, a ideia do determinismo clássico, substituindo-o pela ideia de determinismo estatístico, de forma que o conceito de probabilidade passou a desempenhar um papel essencial na física moderna, como elemento unificador das teorias ondulatória e corpuscular.

Essas considerações iniciais fixavam as ideias básicas do curso, estando de acordo com o pressuposto básico do "plano do curso" segundo o qual as conceituações e proposições mais gerais devem ser apresentadas no início de qualquer processo de instrução. Nas aulas seguintes, ainda na primeira parte do curso (parte de óptica), eram abordados, em detalhes, dentro de um enfoque histórico-fenomenológico-matemático-conceitual, sempre do ponto de vista do modelo de partícula e de onda, os principais fenômenos da óptica clássica (reflexão, refração, difração, interferência e polarização), sem a compreensão dos quais, inclusive nos seus aspectos matemáticos mais simples, torna-se difícil apreciar as sutilezas do comportamento da luz e sua interação com a matéria. Por razões didáticas e pela importância que a descoberta de Roemer teve no desenvolvimento da óptica (de que a luz viaja com velocidade finita, o que é um resultado que respalda a dedução de Huygens, por exemplo, da lei dos senos), foi feita uma revisão histórica dessa descoberta e, para orientar essa discussão, foi produzido o Texto Complementar 1, que pode ser encontrado no Apêndice 4 da tese de doutorado de Rocha (2014), apoiado, em Roemer (1666 apud MAGIE, 1969, p. 335).

\section{Os fenômenos de reflexão, refração, interferência, difração e polarização}

\section{Reflexão}

Na sequência, a reflexão da luz era o primeiro fenômeno a ser estudado. De um conjunto de cerca de dez itens experimentais de interesse, serão citados três para ilustração. Primeiro, o experimento em que duas velas iguais (uma acesa e outra não), eram fixadas dentro de dois copos de vidro vazios iguais (após o que o copo com a vela sem chama era completamente preenchido com água, deixando a vela submersa), e esses eram colocados em lados opostos e distâncias iguais de uma placa de vidro esfumaçado, de forma que, se 
observado de uma posição adequada, o pavio da vela do copo cheio de água parecia ter uma chama submersa na água (Fig. 3). Segundo, o experimento em que se comparava o fenômeno da reflexão da radiação visível com o de um feixe de micro-ondas incidindo em uma superfície semelhante à de uma caçarola de alumínio. Terceiro, o experimento em que se estudavam as imagens formadas por combinações de espelhos e em que se observava, em um dos espelhos, a imagem da mão direita de um dos alunos. Essa última observação geralmente induzia à pergunta: se o espelho inverte a esquerda e a direita, por que também não inverteria em cima e embaixo? Tais experimentos e outros não relacionados aqui, eram acompanhados de discussões teóricas, baseadas na lei da reflexão da luz, deduzida a partir dos modelos corpuscular e ondulatório, e estas discussões eram precedidas de uma breve revisão histórica sobre o assunto, oportunidade em que se relembrava que a lei da reflexão já era conhecida por Euclides de Alexandria no século III a.C. e foi completada, no século XI, pelo físico e matemático iraquiano Al-Hazen, ao enfatizar que o raio incidente, o raio refletido e a normal estão no mesmo plano.

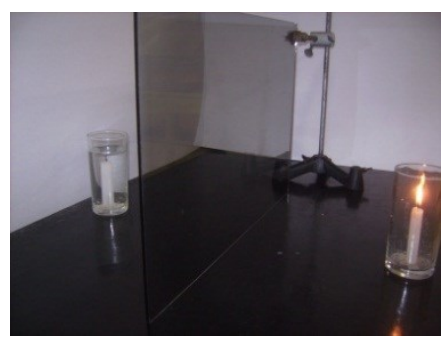

Fig. $3 a$

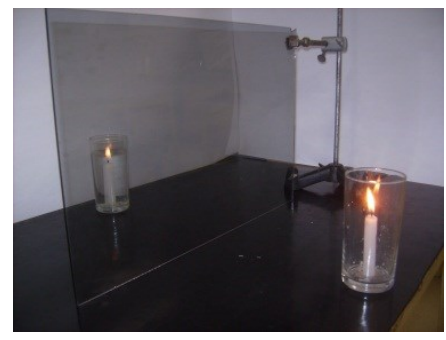

Fig. $3 b$

Fig. 3 - Experimento com duas velas em dois copos, vistos de duas posições diferentes. Na Fig. 3a, o copo da esquerda, cheio de água, com o seu nível acima da altura do pavio, é visto diretamente. Na Fig. 3b, esse mesmo copo é visto através do vidro esfumaçado, o que dá a impressão que a chama da vela está imersa na água. A partir dessa observação e da verificação (por medidas diretas) de que as distâncias das velas à placa são, de fato, iguais, pode-se deduzir que os ângulos de incidência e de reflexão dos raios, na placa, são necessariamente iguais.

É necessário salientar que a dedução teórica da lei da reflexão da luz, a partir do modelo de partícula, não era tão simples quanto poderia parecer, pois, se considerarmos a hipótese de que as partículas de luz são semelhantes a pequenas esferas de matéria, um feixe dessas partículas, incidindo numa superfície como a do vidro, não seria refletido unidirecionalmente e se dispersaria em todas as direções. Newton já considerava esse tipo de dificuldade e acreditava que deveria existir algum "poder do corpo" ou alguma propriedade do corpo distribuída uniformemente pela superfície, a qual atuaria sobre o raio sem contato direto, para que houvesse a reflexão regular. Para Newton: 
A reflexão de um raio é efetuada não por um ponto único do corpo refletor, mas por algum poder do corpo que está espalhado uniformemente por toda sua superficie e pela qual ele age sobre o raio sem contato imediato. Pois que as partes dos corpos agem sobre a luz a distância será mostrado daqui por diante (NEWTON, 1996, p. 201).

O modelo mais simples para representar este "poder do corpo" era o de uma força perpendicular à superfície. À medida que a partícula se aproximasse de outro meio, poderia sofrer reflexão pela ação de uma força repulsiva. Para haver a refração, primeiro a partícula teria de vencer a força repulsiva e, se conseguisse, encontraria uma força atrativa, com a velocidade aumentando no meio mais denso (geralmente mais refringente). Feitos esses comentários, considerava-se então, por interesse pedagógico, a hipótese da luz como partícula, com cada partícula tendo uma quantidade de movimento, $\boldsymbol{p}_{i}$, e sobre a qual, em algum instante, atuava uma força exercida perpendicularmente pela superfície. Nesse modelo simples, supunha-se que o raio incidente fazia um ângulo $\theta$ com a normal, e, com base na ideia de que a componente paralela à superfície não se altera (força perpendicular à superfície), encontrava-se a lei da reflexão da luz. Por outro lado, na dedução da lei da reflexão, a partir do modelo ondulatório, procedia-se de forma análoga ao que Huygens fez em seu livro "Tratado sobre a Luz", publicado em 1690. Para enriquecer as discussões histórico-conceituais sobre o fenômeno da reflexão, dois textos foram produzidos. Um deles, intitulado "A propagação retilínea da luz segundo os modelos de partícula e de onda", e o outro "A Reflexão da luz", que se encontram no Apêndice 4 da tese de doutorado de Rocha (2014), com as indicações Texto Complementar 2 e Texto Complementar 3, respectivamente, e que tiveram como referência principal o livro de Huygens (1986). As referências consultadas para a produção desses dois textos complementares, e dos demais citados neste artigo, foram incluídas, geralmente, no próprio corpo do texto complementar e não ao final de cada um deles.

Como antes, as discussões em sala eram apoiadas ou estimuladas por slides e notas de aula, distribuídas pelo professor, um procedimento que se repetiu nas discussões dos fenômenos de refração, difração, interferência, polarização e outros.

\section{Refração}

No caso do fenômeno de refração, dos oito itens experimentais de interesse, três serão aqui apresentados para ilustração: primeiro, o experimento clássico em que se fazia incidir um feixe de luz laser sobre o lado reto de um bloco semicilíndrico de acrílico, ou vidro, colocado sobre uma escala angular para determinar os vários ângulos de incidência e de refração. Segundo, aquele em que se usava um feixe de luz laser para se determinar o índice de refração de uma placa de vidro, a partir da medida do deslocamento lateral desse feixe; e, terceiro, aquele em que se usava um feixe de luz laser para determinar o índice de refração de um prisma a partir da medida do ângulo de desvio mínimo. É interessante lembrar que, já no 
século XVII, Isaac Newton usava a medida do ângulo de desvio mínimo para determinar o índice de refração de diferentes materiais.

Após a realização dos citados experimentos e de uma breve revisão histórica sobre o tema, o professor, com o tempo otimizado pelo uso de slides, deduzia a lei da refração com base no modelo teórico de Descartes, de 1637 (para quem a luz não era uma partícula, mas a sua transmissão era de caráter corpuscular (DESCARTES, 1937 apud MAGIE, 1969, p. 265)), que prevê velocidade maior para a luz em meios mais densos, resultado que foi motivo de muito debate nos anos que se seguiram, recebendo adesão de alguns cientistas importantes e sofrendo críticas de outros, a exemplo de Pierre de Fermat) Na sequência, deduzia-se a lei da refração com base no modelo ondulatório de Huygens, no qual esse supunha que a luz viaja com velocidade menor nos meios mais densos. Essa lei era usada para calcular o índice de refração do vidro e do acrílico, a partir de algumas medidas feitas na parte experimental. Para orientar e apoiar as discussões em sala de aula, foi produzido o texto intitulado "A lei da refração", que pode ser encontrado no Apêndice 4 da tese de doutorado de Rocha (2014), com a indicação de Texto Complementar 4.

\section{Princípio de Fermat}

A discussão dos modelos teóricos para explicar os fenômenos de reflexão e refração criava a oportunidade para se introduzir o princípio de percurso mínimo, de Heron, e o princípio de tempo mínimo, de Fermat. A relação entre o princípio de Fermat e o princípio de ação mínima, de Pierre L. M. de Maupertuis, era abordada, em seguida, do ponto de vista histórico, precedida naturalmente de sua parte experimental específica, em que se comparava o movimento de duas esferas metálicas, deslocando-se por trajetórias diferentes (ao longo de uma cicloide e ao longo de uma reta, feita em madeira pelo aluno Paulo César Santos de Souza - Fig. 4), partindo, ao mesmo tempo, de pontos de alturas iguais e passando por pontos de alturas menores e também iguais. Essa experiência permitia apresentar o problema da braquistócrona - ou do menor tempo de descida - que, ao lado do Problema de Newton (o de encontrar a forma de uma superfície de revolução, movendo-se em um fluido com velocidade constante na direção do seu eixo), está na raiz da descoberta do chamado cálculo das variações, o qual, por sua vez, teve um papel importante no desenvolvimento do formalismo matemático da Mecânica (Mecânica Analítica) e de Física de modo geral (OZAMIZ 1986; BASSALO; CATTANI, 2011, p. 138). Verificava-se que Maupertuis foi levado a esse princípio, em 1744, ao analisar as críticas que Fermat fazia a Descartes (desde 1637) sobre a dedução da lei da refração da luz, em que este considerava a velocidade da luz maior nos meios mais densos. Um resumo intitulado "A óptica e o princípio de mínima ação de Maupertuis" foi produzido e encontra-se no Apêndice 4 da tese de doutorado de Rocha (2014), com a denominação Texto Complementar 5. 


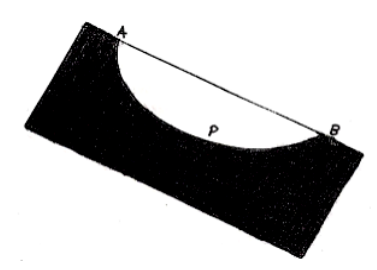

Fig. 4 - Representação de uma peça em madeira, mostrando uma cicloide e uma reta, para a discussão do problema da braquistócrona.

\section{Fenômeno da visão e da visão em cores}

Passava-se então ao estudo do fenômeno da visão e da visão em cores, primeiro do ponto de vista experimental e, depois, histórico-conceitual. Dos seis itens experimentais de interesse, serão descritos dois para ilustrar. Primeiro, o experimento em que se superpunha um feixe de luz monocromática vermelha e outro verde e se obtinha como resultado o amarelo; e, segundo, aquele em que se misturava pigmentos vermelhos e verdes e, ao contrário do caso anterior, não se observava o amarelo. Esses resultados eram discutidos à luz da ideia de combinação de cores primárias no processo aditivo e combinação de cores primárias no processo subtrativo. É claro que era indispensável realizar também o famoso experimento da dispersão de um feixe de luz branca (realizado por Newton com luz natural), em que um feixe de luz produzido por uma lâmpada incandescente sofre dispersão ao atravessar um prisma, sendo, em seguida, projetado numa parede. Esse experimento era completado, fazendo-se o feixe passar por um segundo prisma posicionado adequadamente, para reobter o feixe de luz inicial. Após a realização dos experimentos, passava-se à discussão histórico-conceitual dos fenômenos apresentados, comparando o ponto de vista da teoria newtoniana das cores com o da teoria de Young. Acrescentava-se também as explicações da visão em cores dada pela teoria tricromática de Young-Helmholtz, comparada com a teoria das cores oponentes de Karl E. Hering (1834-1918). Para mostrar como o tema da visão em cores poderia ser relacionado ao problema da natureza da luz, foi produzido um texto intitulado "A visão em cores e os modelos de onda e de partícula", que pode ser encontrado no Apêndice 4 da tese de doutorado de Rocha (2014), com a indicação de Texto Complementar 6.

Após o estudo introdutório da visão em cores, os fenômenos de interferência, difração e polarização (começando pelo fenômeno das cores em películas delgadas, reconhecido hoje como também um fenômeno de interferência) eram explorados exaustivamente, pois conduziam diretamente aos problemas fundamentais da física quântica. A partir desse momento do curso, os fenômenos estudados ganhavam crescentes dificuldades de explicação, o que refletirá nas descrições dos mesmos aqui realizadas, sendo que alguns deles exigirão uma descrição mais detalhada, em razão do tratamento específico, ou não usual, recebido no curso. 


\section{Cores em películas finas}

Ao se iniciar o estudo da interferência de luz, o fenômeno das cores em películas finas, como dissemos, aparecia como o primeiro a ser discutido, o que normalmente não acontece nos livros tradicionais de óptica. Dos vários experimentos demonstrativos previstos, podem-se destacar quatro para ilustração, os quais faziam uso de feixes de luz produzidos por um laser, por uma lâmpada incandescente (de tungstênio) ou por uma lâmpada de vapor de mercúrio. Primeiro, o famoso experimento para mostrar os chamados "anéis de Newton", obtidos facilmente com luz de lâmpada de vapor de mercúrio, incidindo sobre duas placas de vidro colocadas superpostas sobre uma mesa em sala escura, e pressionadas com uma caneta. Segundo, aquele em que cores em uma película de água com sabão, sustentada por uma argola de arame, são obtidas por reflexão da luz de uma lâmpada incandescente (ou de uma lâmpada de vapor de mercúrio) incidindo sobre a película. Terceiro, o experimento em que franjas claras e escuras são observadas com a ajuda de um espectroscópio e um prisma, após a luz de uma lâmpada de tungstênio ser refletida em uma lâmina de mica. E quarto, o experimento em que franjas claras e escuras são observadas em um anteparo, após a luz de um laser ser refletida em lâminas de mica ou de microscópico. A discussão das explicações de Newton a respeito das películas finas, a partir da sua teoria dos "acessos de fácil reflexão e fácil transmissão" (NEWTON, 1996), era realizada logo em seguida, enquanto a explicação desse mesmo fenômeno com base na teoria ondulatória de T. Young, introduzida no início do século XIX, era deixada para um momento posterior.

\section{Difração}

Em seguida, passava-se ao estudo do fenômeno de difração, para o qual existia um grande número de experimentos demonstrativos disponíveis (cerca de quinze). Na maior parte deles, fazia-se um feixe de luz laser incidir em obstáculos e orifícios de tamanhos e formas diferentes, colocados a diversas distâncias da fonte e do anteparo, com destaque para aquele em que aparecia o "ponto de Poisson" ou "ponto de Arago", Mas, no estudo da difração, não só luz laser era usada. Experimentos eram realizados também com luz de lâmpada de tungstênio e com feixe de micro-ondas. Durante as discussões, aproveitava-se para apresentar o próprio relato de Francesco M. Grimaldi (1618-1663), referente ao que denominava "Primeiro Experimento" e "Segundo Experimento", sobre o fenômeno de difração por ele mesmo descoberto (Fig. 5a e 5b). Nesse item era esclarecido ainda que Newton, após publicar os Princípios Matemáticos de Filosofia Natural, voltou a fazer experimentos sobre o fenômeno de difração, mas foi obrigado a interromper tais trabalhos por razões alheias à sua vontade (NEWTON, 1996, p. 250). 


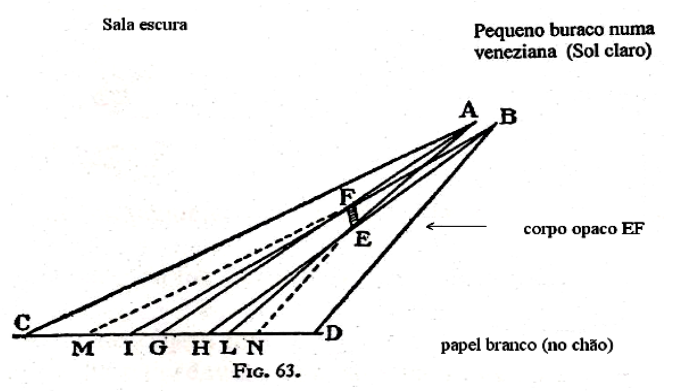

Fig. 5a - "Primeiro Experimento" de Grimaldi. Ele escreve: "Mas o que deve ser especificamente notado é que a sombra IL aparece consideravelmente maior de fato do que deveria ser caso a luz viajasse em linha reta".

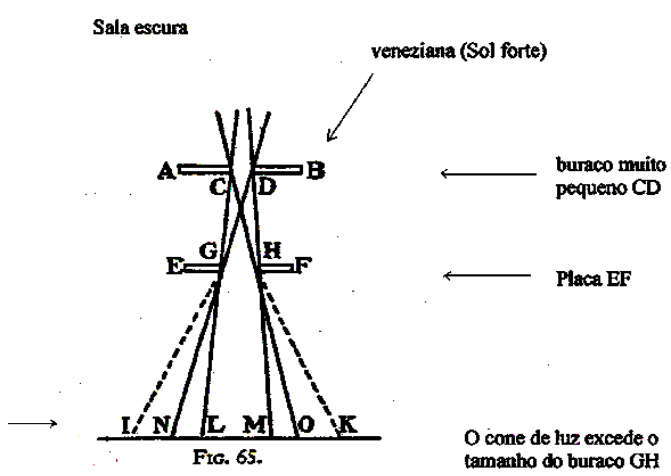

Fig. $5 b$ - "Segundo Experimento" de Grimaldi. Aparece sobre a superficie uma base iluminada IK notavelmente maior que aquela que os raios marcariam se fossem transmitidos em linha reta através do mesmo lado.

\section{Interferência de Young}

Em seguida aos estudos sobre os fenômenos de cores em películas finas e de difração, tomados como preparatórios para a discussão a serem realizadas nas aulas seguintes, passava-se ao estudo das contribuições de T. Young (seguido das de A. Fresnel), relativas ao fenômeno de interferência, datados do início do século XIX, época em que Young realizou seu famoso experimento da dupla fenda. Após revisar o contexto em que Young realizou seus trabalhos, mostrava-se que o princípio da interferência descoberto por T. Young, e redescoberto por A. Fresnel, era um poderoso instrumento para a explicação dos resultados experimentais apresentados anteriormente, produzidos por películas finas (inclusive os "anéis de Newton") e por difração. Nesse momento, eram deduzidas pelo professor as expressões matemáticas para a condição de máximos e de mínimos de interferência no experimento da fenda dupla, como também a condição de mínimo para a difração de fenda única. As expressões matemáticas obtidas eram usadas para a verificação de medidas efetuadas na parte experimental, tanto fazendo uso de luz visível quanto de radiação de micro-ondas. Era também uma oportunidade para se apresentar algumas aplicações modernas do fenômeno de interferência, como o caso da leitora de disco óptico ou de películas finas de substâncias transparentes, colocadas em superfícies das lentes de vidro, para reduzir a reflexão da luz. Aqui a discussão era restrita a feixes intensos de radiação, deixando-se a discussão de experiências com feixes fracos (regime quântico) para outra oportunidade. Para facilitar a compreensão da teoria newtoniana da luz, foi produzido um texto intitulado "Aspectos de corpúsculo e de onda na teoria newtoniana da luz", que está disponível no Apêndice 4 da tese de doutorado de Rocha (2014), com a indicação de Texto Complementar 7. 


\section{Polarização}

Quanto ao fenômeno da polarização da luz, da mesma forma que nos casos anteriores, a parte experimental era a primeira a ser apresentada, seguida, naturalmente, das discussões teóricas, ou histórico-conceituais. Dos cerca de 15 itens experimentais, alguns poderiam ser considerados indispensáveis, a exemplo da experiência demonstrativa na qual a imagem de uma agulha aparecia duplicada, quando colocada entre um cristal de calcita e o vidro de um retroprojetor, iluminando uma tela. Era importante também mostrar o que ocorria quando um feixe de luz laser incidia sobre o cristal de calcita e, em seguida, os feixes emergentes, projetados numa tela, eram analisados com uma placa polarizadora. As diversas experiências com luz, onde eram observados os fenômenos de polarização por dupla refração, por absorção, por reflexão e por espalhamento, não teriam o mesmo impacto se não se dispusessem de pelo menos duas placas polarizadoras de qualidade.

Em razão das características das ondas eletromagnéticas (ondas transversais), o fenômeno de polarização mostrava-se com grande potencial de discussão e, nos debates que se seguiam, os modelos de partícula e de onda eram usados para explicar as observações realizadas. Inicialmente era esclarecido que Étienne Malus, em 1809, estimulado pela Academia de Ciências de Paris - que ofereceu um prêmio a quem apresentasse um estudo matemático da dupla refração e o confirmasse experimentalmente - explicou esse fenômeno como consequência de forças repulsivas, atuando em moléculas luminosas não esféricas, mas arredondadas (modelo corpuscular), que comporiam o raio (ROSMORDUC,1983, p. 85). Em seguida, eram apresentadas as contribuições de T. Young e de Augustin Fresnel, com base no modelo ondulatório da luz, para a explicação do famoso resultado experimental obtido por Arago e Fresnel, em 1816, em que eles, imaginando que só poderia haver interferência de ondas luminosas se estas fossem provenientes de uma única fonte, tentaram interferir os raios emergentes do cristal de calcita (raios ordinários e extraordinários) e notaram que esses não produziam franjas de interferência, formando, em lugar disto, apenas uma iluminação uniforme. Era esclarecido então que a explicação desse fenômeno foi dada por Young e Fresnel, após Young levantar a hipótese de que a luz deveria ser uma onda do tipo transversal, e não longitudinal, e de Fresnel explicar que os raios ordinários e extraordinários emergentes da calcita não produziam franjas de interferência, porque vibravam transversalmente e em direções perpendiculares (HALLIDAY; RESNICK, 1984, p. 249).

Após a apresentação da lei de Malus, que dá a intensidade de um feixe de luz que atravessa um analisador, depois de passar por um polarizador, discutia-se teoricamente a hipótese do feixe de radiação eletromagnética ser suficientemente fraco a ponto de um fóton de cada vez chegar ao analisador. Introduzia-se então a ideia de que tudo que se podia afirmar, nesse caso, era a probabilidade de que o fóton passasse ou não pelo analisador. Faziase então uma aplicação prática dessa ideia, na qual se considerava duas cornetas de microondas (uma emissora e outra receptora) colocadas frente a frente, com um amperímetro acoplado à corneta receptora e com as antenas emissora e receptora, orientadas, inicialmente, 
numa direção designada pelo ângulo $\theta$. Supunha-se então a corneta emissora de micro-ondas emitindo um fóton de cada vez, e se tentava responde a seguinte questão: Qual seria a probabilidade desse fóton ser detectado pela corneta receptora se esta fosse reorientada para a direção $\varphi$ ? Ou melhor: Qual a probabilidade de o fóton preparado no estado de polarização $\theta$ ser detectado no estado de polarização $\varphi$ ? O resultado calculado para uma reorientação de $45^{\circ}$ dava uma probabilidade de $50 \%$, e esse resultado era então relacionado com os valores de corrente indicados no aparelho, antes da reorientação, $i_{o}$, e depois da reorientação, $i$, (no detector chegavam muitos fótons de cada vez, no mesmo estado, o que era equivalente à chegada de um fóton de cada vez, para efeito de comparação dos resultados experimentais com as previsões teóricas). Verificava-se então que a relação entre os valores de corrente lidos antes $(1 \mathrm{~mA})$ e depois da reorientação da antena receptora (aproximadamente $0,7 \mathrm{~mA}$ ) confirmava a previsão teórica do cálculo probabilístico (nesse experimento, a corrente era proporcional à componente do campo elétrico na direção da antena), previsão essa que era feita a partir da reinterpretação (em termos de probabilidade) da lei de Malus, que é dada por $I=I_{\mathrm{o}}\left[(\cos (\theta-\varphi)]^{2}\right.$, onde $I_{\mathrm{o}}$ é a intensidade da radiação antes de passar no analisador, e $I$, após isso ocorrer.

Após o estudo do fenômeno da polarização, era realizada a primeira avaliação da aprendizagem, para apreciar o rendimento acadêmico dos alunos, quando, geralmente, eram convidados a responder seis a dez questões tratando de aspectos históricos, fenomenológicos e conceituais do curso.

\section{Redes de difração}

A seguir, pretende-se analisar historicamente como a parte de física moderna do curso, reservada, explicitamente, à introdução das noções da teoria da relatividade e física quântica, foi apresentada aos alunos. Relembramos, inicialmente, que no primeiro e no segundo semestres de oferecimento da disciplina, tal parte foi desenvolvida com base no material produzido pela professora Ileana Greca, mas que isso não aconteceu nos demais semestres. Em semestres posteriores, essa parte do curso era iniciada com a realização de experimentos, seguida da discussão das propriedades das redes de difração unidimensional, bidimensional e tridimensional, com atenção voltada para a rede tridimensional, que era utilizada, posteriormente, ao se discutir a simulação de experiências de raios-x, usando microondas. $\mathrm{O}$ uso de radiação de micro-ondas para simular experiências de raios-x era muito importante dentro da programação do curso, pois essa radiação era utilizada, posteriormente, na discussão das ondas de matéria, propostas por Louis de Broglie, em 1923, e verificadas, entre outros, por C. Davisson e L. Germer, para elétrons, zem 1927, pois a experiência com o feixe de raios-x, simulada com o uso de micro-ondas, era análoga à experiência de Davisson e Germer, com um feixe de elétrons.

Dos cerca de dez itens experimentais referentes ao estudo das propriedades dos diversos tipos de rede de difração, serão destacados três, com o intuito de evidenciar os passos 
necessários (de dificuldades crescentes) a serem dados para que seja alcançada uma melhor compreensão do fenômeno de difração em redes tridimensionais. Primeiro, aquele em que, usando um espectrômetro, observava-se a luz de uma lâmpada de mercúrio através de uma rede unidimensional, começando com a observação da difração em uma fenda, de duas, de três, de dez e de um número muito grande de fendas (uma rede de difração com 600 linhas $/ \mathrm{mm}$ ). Segundo, aquele em que se observava a figura produzida por um feixe de luz laser após esse incidir sobre uma rede bidimensional de difração, e, terceiro, o experimento em que se fazia incidir radiação de micro-ondas (comprimento de onda de aproximadamente 3 $\mathrm{cm})$ sobre um arranjo tridimensional de esferas metálicas posicionadas a iguais distâncias umas das outras, no interior de um cubo de isopor. A incidência de radiação de micro-ondas sobre esse arranjo tridimensional permitia o estudo da difração por uma rede tridimensional, numa escala cerca de $10^{8}$ vezes maior que a de raios-x, pois a radiação de micro-ondas tem comprimento de onda cerca de $10^{8}$ vezes maior que a de raios-x e as distâncias entre as esferas metálicas (centro difratores) também tinham dimensões $10^{8}$ vezes maiores que as de um cristal real.

Após se fazer uma revisão histórica do papel desempenhado pelas redes de difração no desenvolvimento da física moderna, onde era discutida a sua importância para o desenvolvimento da física quântica, passava-se à discussão dos aspectos matemáticos das redes. O primeiro passo era a dedução da "equação da rede" para o caso unidimensional, sob incidência normal. Mostrava-as então que a equação da rede unidimensional, com incidência normal, tem uma forma bastante simples, dada por: $\delta \operatorname{sen} \theta=n \lambda$, onde $\theta$ é o ângulo de difração; $\delta$, a distância entre as fendas; $\lambda$, o comprimento de onda da radiação e, $n$, um número inteiro. Os aspectos matemáticos das redes bidimensionais não eram muito relevantes para o curso e, por esta razão, optava-se por explorar mais extensamente os aspectos matemáticos das redes tridimensionais, que, como dissemos, permitiam uma rica discussão da experiência em que se simulava a difração de raios-x ("Difração de Bragg"), usando micro-ondas. Em seguida, passava-se à dedução da chamada lei de Bragg, uma expressão matemática deduzida pelo físico inglês, W. L. Bragg, em 1912, com base no modelo ondulatório da luz, ao estudar a interferência de raios-x espalhados pelos átomos distribuídos em várias famílias de planos paralelos, agora chamados planos de Bragg. A expressão matemática obtida era escrita na forma: $2 d \operatorname{sen} \theta=m \lambda$, onde $d$ é a chamada distância interplanar; $\theta, o$ ângulo entre o feixe incidente (ou refletido) e o plano no qual o feixe incide; $\lambda$, o comprimento de onda da radiação; e $m$, um número inteiro (Fig. 7).

\section{A difração e a constante de Avogadro}

Essa experiência permitia também a introdução de uma proveitosa discussão sobre a determinação experimental da constante de Avogadro por meio de técnicas de difração. Para tornar a explicação mais simples, supunha-se que cada átomo da amostra cristalina estava posicionado no centro de um cubo de aresta $a$, onde $a$ é, equivalentemente, a distância entre 


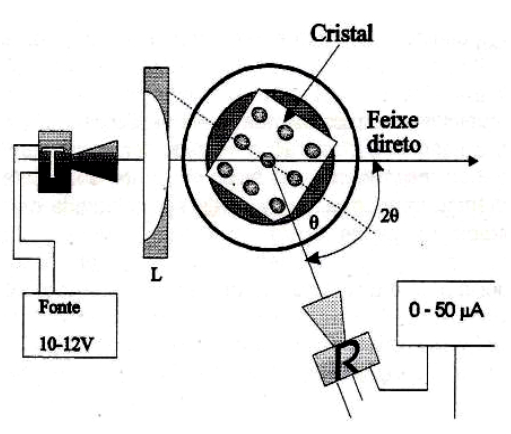

Fig. 7 - Arranjo experimental para a obtenção dos picos de difração. Figura extraída da apostila "Textos de Laboratório", do Departamento de Física do Estado Sólido do IFUFBA.

os centros dos átomos. Mostrava-se então que a constante de Avogadro podia ser avaliada, a partir da medida da distância entre os planos (100), que, nesse caso, é igual à distância entre os centros dos átomos da amostra. Após a medida da distância entre os planos (100), estimava-se a constante de Avogadro a partir da expressão $\rho=(M / V)$, em que $\rho$ é a densidade da amostra (valor encontrado em tabelas de densidade), $M$ é a massa molar (valor extraído da tabela periódica) e $V$ é o volume de um mol, dado por $V=N_{A} a^{3}$, onde $a$, como já foi dito, é a distância entre os centros dos átomos. Se a distância interplanar obtida fosse de 3,35 cm (na nossa amostra a distância interplanar era de 4,0 cm), diríamos que o citado arranjo tridimensional de esferas metálicas estaria simulando muito bem uma amostra de polônio (que tem uma estrutura cúbica simples. Nesse caso, a constante de Avogadro seria estimada em: $N_{A}=M / \rho a^{3}=(209 \mathrm{~g} / \mathrm{mol}) /\left[\left(9,3 \mathrm{~g} / \mathrm{cm}^{3}\right) \times\left(3,35 \times 10^{-8} \mathrm{~cm}\right)^{3}\right]=6,0 \times 10^{23}$ átomos $/ \mathrm{mol}$, onde a massa molar do polônio, $M$, foi tomada como $209 \mathrm{~g} / \mathrm{mol}$, a densidade, $\rho$, foi assumida como 9,3 $\mathrm{g} / \mathrm{cm}^{3}$, a uma certa temperatura, e a distância entre os átomos foi assumida ser de $3,35 \times 10^{-8}$ $\mathrm{cm}$ (à mesma temperatura), tendo sido incluído o fator de $10^{-8}$ pelo fato de a simulação ser feita numa escala $10^{8}$ vezes maior que as experiências realizadas com raios-x. A constante de Avogadro, sem a unidade $\mathrm{mol}^{-1}$, é o número de Avogadro.

\section{Planck, Einstein, L. de Broglie, Schrödinger...}

\section{Experiência de Michelson-Morley}

As discussões sobre onda de matéria, referidas anteriormente, eram antecedidas ainda pela apresentação de três temas importantes: a Experiência de Michelson-Morley, a Radiação do Corpo Negro e o Efeito Fotoelétrico. Como nos casos anteriores, os assuntos apresentados eram sempre apoiados por experimentos demonstrativos, sendo o caso da radiação do corpo negro o mais difícil de ser tratado em um curso dessa natureza. Começavase com a discussão do experimento de Michelson-Morley que servia de veículo para a introdução de noções da teoria da relatividade especial (relatividade restrita). O primeiro passo era a apresentação do interferômetro de Michelson, a partir do qual se mostrava o efeito 
que seria observado no interferômetro, caso o suposto éter de fato influenciasse o resultado. Tal apresentação era acompanhada por uma revisão histórico-conceitual centrada no problema da relatividade do movimento, que, como se sabe, remonta à Grécia antiga, quando filósofos importantes, como Aristarco de Samos, ousaram considerar um sistema heliocêntrico, em contraposição a um sistema geocêntrico, para descrever o movimento dos corpos celestes (OLIVEIRA FILHO; SARAIVA, 2014, p. 66). Para orientar as discussões sobre esse tema, foi produzido um texto-resumo que pode ser encontrado no Apêndice 4 da tese de doutorado de Rocha (2014), com a denominação de Texto Complementar 8.

\section{Radiação de corpo negro}

Após a discussão do experimento de Michelon-Morley, passava-se ao estudo da chamada radiação do corpo negro, que recolocou no centro das discussões científicas o problema da natureza da luz em um momento que parecia não mais haver dúvida quanto à sua constituição, em razão do sucesso espetacular da teoria eletromagnética clássica, desenvolvida por Maxwell e outros (ROCHA, 2015). A parte experimental do estudo da radiação do corpo negro era baseada no artigo de Cavalcante e Haag (2005), intitulado Corpo negro e determinação experimental da constante de Planck. Com base nas ideias principais desse artigo, devidamente adaptadas para o curso de Física Básica IV, procedia-se à determinação experimental (de forma aproximada) da constante de Stephan-Boltzmann, $\sigma$ (relacionada à constante de Planck, $h$, através da expressão para a potência por unidade de área irradiada por um corpo negro, $\sigma T^{4}=\left(8 \pi^{5} k^{4} / 60 h^{3} c^{2}\right) T^{4}$, onde, $c$ é a velocidade da luz no vácuo e $k$ é a constante de Boltzmann (TIPLER, 1981, 89)), a partir de medidas simples de tensão e de corrente, quando essa corrente passava através do filamento de tungstênio de uma lâmpada de farol de automóvel, ou de uma lâmpada equivalente. Para encontrar o valor da constante de Stefan-Boltzmann, o primeiro passo era determinar a temperatura do filamento, sendo necessário também avaliar a área de sua superfície. $\mathrm{O}$ espectro da radiação emitida pelo filamento aquecido era observado com a ajuda de um espectrômetro de prisma e relacionado, qualitativamente, pelo professor, com as curvas da Radiância Espectral estudadas, experimentalmente, por Heinrrich Rubens, Ferdnand Kurlbaum e outros, em 1900, as quais tiveram um papel importante na descoberta, por Planck, dos quanta de energia. O tempo reservado para o estudo desse tema era relativamente curto, mas as discussões sobre a radiação do corpo negro, mesmo limitadas no tempo, mostravam-se importantes, por se tratar do tema fundador da física quântica, e serviam de ponto de apoio aos estudos que se seguiam. As dificuldades dos alunos para entenderem o problema da radiação do corpo negro, num tempo tão curto, se deviam, em parte, à própria complexidade desse problema, cuja discussão envolvia, simultaneamente, conceitos não simples do eletromagnetismo clássico e da termodinâmica, mas, de qualquer modo, a discussão era importante para introduzir qualitativamente o conceito de quantum de energia. Para relacionar as medidas de tensão e de corrente com a constante de Stephan-Boltzmann e com a constante de Planck, e orientar as 
discussões em sala de aula, foi produzido um texto-resumo de cunho históricofenomenológico-conceitual, que pode ser encontrado no Apêndice 4 da tese de doutorado de Rocha (2014), com a designação de Texto Complementar 9.

\section{Efeito fotoelétrico}

Em continuação, estudava-se o chamado efeito fotoelétrico. Esse era um tema que se mostrava indispensável num curso como o de Física Básica IV, pela sua simplicidade e riqueza conceitual, e esta foi a razão pela qual foi dedicado um tempo maior a sua apresentação. Como de praxe, primeiro eram apresentados os itens experimentais de interesse, usando-se equipamentos do laboratório da disciplina Estrutura da Matéria, onde se mostrava (em um amperímetro) o aparecimento da corrente fotoelétrica, em razão da incidência de um feixe de luz sobre a célula fotoelétrica. Mostrava-se também que esta corrente podia ser reduzida se uma diferença de potencial $(\mathrm{V})$ fosse aplicada entre as placas para desacelerar os fotoelétrons, chegando-se a determinar, inclusive, o valor da diferença de potencial $\left(\mathrm{V}_{\mathrm{o}}\right)$ para o qual a corrente tornava-se zero, indicando que somente os fotoelétrons, que têm energia cinética inicial maior que $\left|e V_{o}\right|$, podiam atingir a placa oposta. Após a apresentação desta parte experimental, uma longa discussão histórico-matemático-conceitual era realizada, fazendo-se uso, inclusive, de dados publicados pelo próprio Milikan, em 1916 (HECHT, 1991, p. 570). Para orientar tais discussões, foram produzidas algumas notas de aula, mostrando como o estudo desse tema evoluiu desde a descoberta desse efeito, por Hertz, em 1887 (ou pelo físico russo Aleksandr Stoletov, em 1872, como citado por alguns autores) até 1915, quando R. Millikan, finalmente, confirmou as explicações de Einstein para esse fenômeno com base na concepção da luz como partícula. As notas de aula sobre o efeito fotoelétrico podem ser vistas no Apêndice 4 da tese de doutorado de Rocha (2014), sob a designação de Texto Complementar 10.

\section{Ondas de matéria}

O passo seguinte às discussões sobre o efeito fotoelétrico era o da introdução da noção de onda de matéria, tomando-se como referência a experiência de difração de raios-x, que, como já foi observado, tinha a mesma base conceitual que a experiência de Davisson e Germer, mudando-se apenas o tipo de radiação que se fazia incidir na amostra cristalina. Esse paralelo com a experiência de difração de raios-x, permitia que fossem comparadas as previsões teóricas baseadas nas ideias de L. de Broglie, publicadas em 1923, com os resultados experimentais obtidos por Davinson e Germer, em 1927. As discussões realizadas em sala foram orientadas por notas de aula que podem ser encontradas no Apêndice 4 da tese de doutorado de Rocha (2014), com a indicação de Texto Complementar 11.

A introdução da noção de ondas de matéria criava a oportunidade também de se evidenciar a importância das contribuições de Louis de Broglie, A. Einstein e E. Schrödinger para o desenvolvimento da chamada Mecânica Ondulatória, simbolizada pela famosa equação 
de onda, que ficou conhecida como equação de Schrödinger e que geralmente é escrita na forma:

$$
\left[-\left(h^{2} / 4 \pi^{2}\right)(1 / 2 m)\left(\partial^{2} / \partial x^{2}+\ldots\right)+U(\boldsymbol{r}, t)\right] \Psi(\boldsymbol{r}, t)=i(h / 2 \pi) \partial \Psi(\boldsymbol{r}, t) / \partial t
$$

onde $m$ é a massa da partícula num campo potencial $U, h$ é a constante de Planck e $\Psi(r, t)$ é a chamada função de onda associada à partícula.

Para entender qualitativamente a pista seguida por Schrödinger (após os trabalhos de L. de Broglie) para a obtenção de sua famosa equação, foi tomado como referência o diagrama da Fig. 8. Ao comentar esse diagrama, primeiro deve-se dizer que antes de Schrödinger obter sua famosa equação já era de seu conhecimento que o cientista inglês W. Hamilton (1805-1865), na década de 1830, tinha descoberto uma analogia entre a óptica geométrica e a mecânica clássica (ver lado direito do retângulo da Fig. 8). Sabia também que, com as descobertas de A. Fresnel e outros, no início do século XIX, a óptica geométrica tinha passado a ser considerada como um caso limite da óptica física, válida nas situações em que o comprimento de onda da luz $(\lambda)$ era muito pequeno, comparado com as dimensões típicas $(d)$ envolvidas na propagação das ondas $(\lambda / d<<1)$, tal como tamanho de obstáculos ou de orifícios (ver lado superior da Fig. 8). Por outro lado, em 1925, Louis de Broglie já tinha publicado suas descobertas e considerava que seria possível obter o fenômeno de difração em situações em que o comprimento de onda das ondas de matéria fosse suficientemente pequeno, comparável às distâncias interatômicas, como no caso de raios-x. Com tudo isso, Schrödinger compreendeu que poderia criar uma nova mecânica de ondas (ondas de matéria), inspirando-se na óptica física (ondulatória) e nas relações $p=h / \lambda$, e $E=h v$, propostas por L. de Broglie, de forma que houvesse uma analogia entre a óptica física e a nova mecânica de ondas (ver lado esquerdo da Fig. 8). Se as leis dessa nova mecânica fossem descobertas, elas poderiam ter a mecânica clássica como um caso limite (ver lado de baixo da Fig. 8)

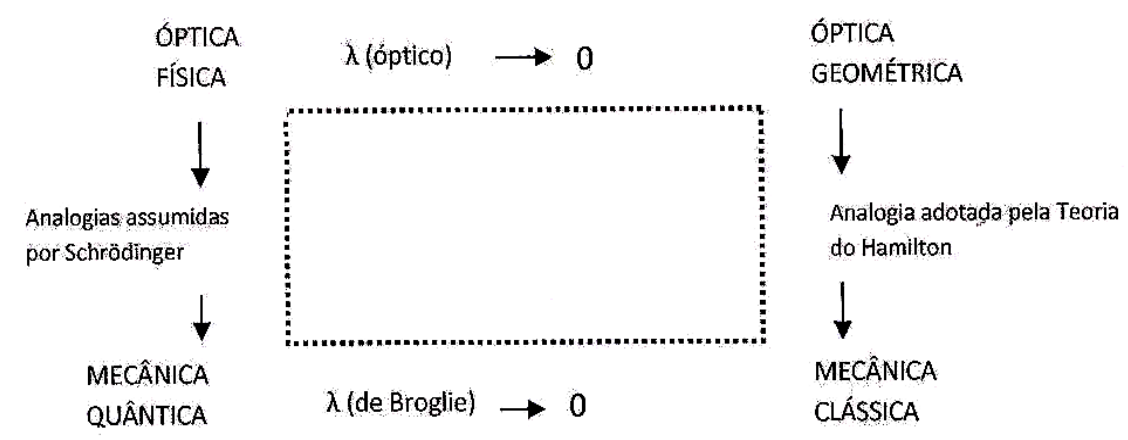

Fig. 8-O esquema mostra a analogia entre óptica geométrica e mecânica clássica adotada por Hamilton e também a analogia entre óptica física e mecânica quântica, adotada por Schrödinger. 
Na Parte II de seu citado artigo de 27 de janeiro de 1926, recebida para publicação em 23 de fevereiro de 1926, Schrödinger assim se referiu à citada analogia entre mecânica e óptica:

Nossa mecânica clássica é talvez completamente análoga à óptica geométrica e por isso falha e está em desacordo com a realidade [...] Portanto é preciso estabelecer uma mecânica ondulatória, e o método mais óbvio é a elaboração de uma teoria ondulatória a partir da analogia hamiltoniana (SCHRÖDINGER, 1926, p. 18).

Após a apresentação da equação de Schrödinger, discutia-se a interpretação da função de onda, $\Psi(\boldsymbol{r}, t)$, dada por Max Born, em junho de 1926, inspirado em uma interpretação sugerida por Einstein para o caso de fótons, segundo a qual o quadrado da amplitude de uma onda luminosa poderia ser visto como uma densidade de probabilidade de ocorrência de fótons. Por analogia, Max Born propôs que o quadrado (do módulo) da função de onda poderia ser visto como a densidade de probabilidade de ocorrência da partícula material.

As quase quatro horas de aulas semanais da disciplina, geralmente, permitiam que se avançasse até o tema ondas de matéria e, às vezes, um pouco mais. Em pelo menos um semestre, houve a oportunidade de se discutir teoricamente o texto apresentado no Apêndice 4 da tese de doutorado de Rocha (2014), com a denominação de Texto Complementar 12, que dá uma visão geral das experiências mais recentes, com feixes de radiação suficientemente fracos, explorando o problema da natureza da luz.

É importante salientar, mais uma vez, que a programação das atividades desenvolvidas na disciplina Física Básica IV, na forma descrita até aqui, passou por contínuos ajustes pontuais, como não poderia deixar de ser, desde a primeira vez em que foi oferecida, no ano 2000. Alguns desses ajustes foram tratados nos itens II e III, deste trabalho, sendo que mudanças ocorreram também ora pelo acréscimo de uma nova experiência ou exclusão de uma que estava sendo utilizada (por se revelar não plenamente ajustada aos propósitos do curso), ora pela revisão pontual de um texto complementar e notas de aula correspondentes, ou mesmo pela produção de um novo texto. A limitação de tempo também foi razão por excluir um ou outro tópico previsto na programação, como foi o caso do "Átomo de Bohr", em benefício de outros tópicos, como o conceito de dualidade.

A seguir será apresentada a avaliação da abordagem utilizada na disciplina Física Básica IV.

\section{Metodologia utilizada na avaliação da abordagem na disciplina}

Como anunciado na Introdução, a avaliação da abordagem utilizada na disciplina Física Básica IV (atual Conceitos dos de Física $D$ ) será baseada no trabalho de Rocha (2014), que fez uso de dados coletados através da metodologia da história oral e de questionários abertos, aplicados pelo professor em dois semestres diferentes, quais sejam, os semestres 
2001.2 ( $2^{\mathrm{a}}$ vez em que a disciplina foi oferecida) e 2011.2. Antes de apresentarmos os dados obtidos através desses recursos, entretanto, faremos um breve comentário sobre a metodologia da história oral, visando a situá-la neste trabalho.

Do ponto de vista historiográfico, história oral não se confunde com gravação de entrevista. De acordo com Meihy e Ribeiro (2011, p. 12): história oral é um conjunto de procedimentos que se iniciam com a elaboração de um projeto e que continua com a definição de um grupo de pessoas a serem entrevistadas. Observa-se, portanto, que a metodologia da história oral privilegia a formulação do um projeto como ato fundador, entendendo-se por projeto, o plano capaz de articular argumentos operacionais de ações desdobradas de planejamentos de pesquisas prévias sobre algum grupo social que tem algo a dizer (MEIHY; RIBEIRO, 2011, p. 13). Ainda de acordo com esses autores, em história oral as entrevistas devem ser gravadas como parte de uma proposta orientada para produzir efeitos e devem ser entendidas como: encontros planejados, gravados por diferentes mídias, decorrentes de projetos exercitados de maneira dialógica, ou seja, com perguntas/estímulos e respostas. As entrevistas devem permitir mais do que dados informativos, devem permitir entender situações propostas como problemáticas, com versões diferentes ou desconhecidas de fatos, ocorrência ou visão de mundo. No caso dessa experiência de ensino, o plano definidor das entrevistas decorreu da necessidade de analisar a repercussão, entre docentes e discentes, da matriz curricular do Curso de Física, Licenciatura, noturno, na qual se inclui o conjunto das Físicas Básicas (atuais Conceitos de Física), em particular, a Física Básica IV. Em razão dos objetivos deste artigo, apresentaremos neste trabalho as opiniões avaliativas dos atores históricos referentes apenas à abordagem utilizada na disciplina Física Básica IV, podendo o estudo completo ser encontrado na tese de doutorado de Rocha (2014, p. 203).

A seguir, serão apresentadas, primeiro, as opiniões avaliativas dos discentes, obtidas através de resposta a questionários, distribuídos ao final dos dois semestres referidos; em continuação, serão apresentadas as opiniões avaliativas de discentes, obtidas através da metodologia da história oral, e também do docente que a ministrou em parceria com um colega, nos dois primeiros semestres em que essa disciplina foi oferecida.

\section{V.1 Opiniões avaliativas dos discentes obtidas através de respostas a questionários}

Na primeira vez em que foi oferecido (semestre 2000.2), a receptividade dos alunos ao curso de Física Básica IV não foi verificada explicitamente. Uma primeira coleta de opinião (escrita) foi feita apenas na segunda vez em que o curso foi ministrado, na mesma configuração, no segundo semestre do ano seguinte (2001.2). Após o término desse semestre, instados pelo professor, 10 dos 14 alunos matriculados manifestaram suas opiniões sobre o curso ministrado e a avaliação que faziam de seu próprio desempenho. As opiniões avaliativas dos discentes sobre o curso ministrado podem ser vistas no Quadro 1. 
Quadro 1 - Opiniões avaliativas discentes sobre a abordagem utilizada na disciplina Física Básica IV - semestre 2001.2.

\begin{tabular}{|c|c|}
\hline Alunos & Respostas dos alunos a como avaliavam o curso de Física Básica IV \\
\hline Aluno 1 & $\begin{array}{l}\text { R: } \\
\text { A primeira parte da disciplina }[\ldots] \text { atendeu plenamente as minhas expectativas } \\
\text { (demonstrações, experimentos, discussões, abordagem histórica, filmes etc.) salvo a } \\
\text { indefinição sobre a avaliação da aprendizagem desde o início do curso. } \\
\mathrm{Na} \text { segunda parte [...], o começo foi com textos interessantes, que geravam boas } \\
\text { discussões e debates, contudo, à medida que o curso foi sendo adiantado, os textos } \\
\text { foram perdendo o "significado físico", as discussões já não aconteciam com a mesma } \\
\text { frequência e intensidade, chegou o momento em que queríamos nos livrar dos textos. } \\
\text { Eu acho que esta parte do curso deveria seguir a linha das primeiras aulas (textos sobre } \\
\text { ideias da Física Quântica, comparação destas ideias com as atuais, mais aulas } \\
\text { expositivas, experimentos etc.). [...] }\end{array}$ \\
\hline Aluno 2 & $\begin{array}{l}\text { R: } \\
\text { No decorrer do curso, pude verificar o número suficiente de aulas práticas, nas quais } \\
\text { foram expostos os fenômenos direcionados aos tópicos do curso. As discussões dos } \\
\text { fenômenos foram feitas de forma clara e objetiva. Apenas sugeriria que fosse feita uma } \\
\text { avaliação para cada aula de laboratório, o que iria nortear os alunos a aprofundar as } \\
\text { discussões, elevando assim o aprendizado. } \\
\text { As aulas teóricas foram dadas com clareza e objetividade. Foram levantadas também } \\
\text { algumas questões importantes acerca de tópicos do curso e resolvidas, também, com } \\
\text { clareza. } \\
\text { Tenho a plena convicção de que o nível do curso foi muito bom e com proporcional } \\
\text { interesse dos alunos e por parte do professor, que interagiu conosco com segurança e } \\
\text { disponibilidade. [...] }\end{array}$ \\
\hline Aluno 3 & $\begin{array}{l}\text { R: } \\
\text { Foi extremamente importante e proveitoso o fato de irmos ao laboratório de Óptica } \\
\text { para realizar os experimentos. Entretanto, creio que o aproveitamento seria maior se } \\
\text { pudéssemos, em equipes, montar os dispositivos de observação, afinal estamos nos } \\
\text { formando como condutores dos experimentos no futuro e não cabe apenas assistir no } \\
\text { presente. } \\
\text { As listas de exercício são ferramentas de discussões e acho que deveriam ter uma } \\
\text { quantidade menor de questões para possibilitar a discussão em sala de aula, como } \\
\text { fizemos na } 2^{\mathrm{a}} \text { parte do curso pelo grupo inteiro ou por equipe. } \\
\text { É necessário que a } 2^{\mathrm{a}} \text { parte do curso tenha um dinamismo maior. O conhecimento do } \\
\text { professor [...] é indiscutível mas por tratar-se de conceitos que não são aceitos de forma } \\
\text { elementar (a mecânica quântica exige conhecimento e abstração), é preciso imaginar e } \\
\text { tentar apresentar manifestações destes efeitos (como por exemplo o cartaz sobre o } \\
\text { microscópio por tunelamento, que encontramos no } 4^{\circ} \text { andar). }\end{array}$ \\
\hline Aluno 4 & $\begin{array}{l}\text { R: } \\
\text { Apesar de ter faltado algumas aulas devido a questões de trabalho, acho que o curso foi }\end{array}$ \\
\hline
\end{tabular}




\begin{tabular}{|c|c|}
\hline & $\begin{array}{l}\text { muito proveitoso, pois discutimos pontos importantes que "abriu minha mente" ao } \\
\text { entendimento, atingindo assim o objetivo do curso que é preparar o aluno para a Física } \\
\text { Geral e Experimental IV. } \\
\text { Como sugestão acho que as listas de exercício devem ser feitas no laboratório após os } \\
\text { experimentos. }\end{array}$ \\
\hline Aluno 5 & $\begin{array}{l}\text { R: } \\
\text { Acho que todos aprendemos (nos aprimoramos) com a disciplina. Uma boa proposta } \\
\text { para o curso seria a de se fazer três ou quatro listas, em "sala de aula", com discussões } \\
\text { em grupo, o aluno se deteria nas questões e tiraria as dúvidas durante a resolução da } \\
\text { lista. [...] }\end{array}$ \\
\hline Aluno 6 & $\begin{array}{l}\text { R: } \\
\text { Em relação ao curso, me mostrou ter sido muito bem preparado, com grande empenho } \\
\text { do professor no preparo das aulas. Acredito que o método de avaliação não foi muito } \\
\text { bem sucedido (sic), necessitando de certa reflexão, no âmbito de achar um modo mais } \\
\text { eficiente. Gostaria de parabenizar o enfoque fenomenológico da matéria, única } \\
\text { abordagem deste tipo no meu curso até agora. }\end{array}$ \\
\hline Aluno 7 & $\begin{array}{l}\text { R: } \\
\text { A introdução das Físicas Básicas (I, II, III e IV) para o curso noturno para mim está } \\
\text { sendo muito bom. [...] } \\
\text { Em relação à avaliação penso que a melhor forma seria observar o experimento e } \\
\text { resolver as questões no laboratório como no curso de Física Básica III [semestre } \\
2001.1 \text { ] }\end{array}$ \\
\hline Aluno 8 & $\begin{array}{l}\text { R: } \\
\text { Creio que acima dos exercícios e provas propostas fui bastante tocado com os } \\
\text { estímulos aos alunos do professor em sala de aula. [...]. }\end{array}$ \\
\hline Aluno 9 & (Este aluno limitou-se a avaliar seu próprio desempenho no curso.) \\
\hline Aluno 10 & ém limitou-se a avaliar seu próprio desempenho no curso). \\
\hline
\end{tabular}

Fonte: ROCHA (2014).

Nas respostas dos alunos ficou evidenciado que o curso foi constituído de duas partes, a de óptica e a de física moderna. No geral, as opiniões foram de aprovação, com algumas críticas localizadas. Houve destaque positivo para a abordagem histórica e para as discussões dos fenômenos observados no laboratório de óptica, em consonância com o que foi apresentado na subseção IV.2. Houve também sugestões de inclusão de experimentos na parte de física moderna e mais dinamismo em sala. Um dos alunos considerou que, na parte de física moderna, os primeiros textos utilizados em sala de aula, extraídos da mencionada tese de Ileana Greca (utilizada apenas nos dois primeiros semestres em que a disciplina foi oferecida, como mencionado no segundo parágrafo da seção II), foram interessantes, sendo capazes de gerar boas discussões e debates, mas, à medida que o curso foi avançando, os textos seguintes já não tinham a eficiência dos primeiros e "chegou um momento que 
queríamos nos livrar dos textos". Outro aluno mostra acreditar que o objetivo do curso de Física Básica IV é preparar o estudante para a disciplina Física Geral e Experimental IV. Houve críticas à forma como foi feita a avaliação da aprendizagem dos alunos e houve também muitas sugestões de como fazer tal avaliação nesse tipo de curso. Sugestões também foram feitas no sentido de discutir as listas de exercício em sala de aula. Alguns alunos limitaram-se a avaliar seu próprio desempenho no curso, sem manifestar opinião sobre o desenvolvimento do mesmo. Apesar das ressalvas, o curso foi considerado de nível "muito bom".

Uma nova coleta de opinião dos alunos foi realizada no semestre 2011.2, e, dos 9 alunos matriculados, apenas 4 responderam por escrito à solicitação do professor, entregando seus depoimentos após o término do semestre. A seguir, no Quadro 2, será transcrito o resultado da coleta de opinião sobre os seguintes itens: a) aspectos positivos do curso; b) aspectos negativos; c) autoavaliação e d) sugestões para melhorar o curso.

Quadro 2 - Opiniões avaliativas dos discentes sobre o curso de Física Básica IV - semestre 2011.2.

\begin{tabular}{|l|l|}
\hline Alunos & \begin{tabular}{l} 
Respostas dos alunos aos itens: \\
a) aspectos positivos do curso; \\
b) aspectos negativos; \\
c) autoavaliação e \\
d) sugestões para melhorar o curso. \\
\hline Aluno 1
\end{tabular} $\begin{array}{l}\text { Quanto aos aspectos positivos (item a): } \\
\text { O Aluno 1, no que diz respeito a esse item (aspectos positivos), desdobrou sua resposta } \\
\text { em seis pontos. } \\
\text { R: } \\
\text { i) O desenvolvimento gradativo de temas permite um entendimento muito mais } \\
\text { significativo dos mesmos, uma vez que há bastante espaço para debates, } \\
\text { questionamentos, enfim, é possível não entender primeiro para depois entender } \\
\text { verdadeiramente. } \\
\text { ii) A técnica é a parte integrante da cultura humana, e por ser parte torna criminosa } \\
\text { qualquer tentativa de reduzir o conhecimento ao aspecto puramente técnico. O } \\
\text { andamento das aulas, permeadas por aspectos históricos da evolução da ciência liberta } \\
\text { os estudantes do velho esquema de aplicação de técnicas matemáticas o tempo inteiro. } \\
\text { Penso que esse caminho serve a um duplo propósito: mostrar as relações entre o } \\
\text { conhecimento científico e o contexto no qual está inserido e do qual é também resultado, } \\
\text { e dar vida, sentido, cores ao estudo da Física, lembrando-nos de que isto deve ser } \\
\text { também uma atividade bastante prazerosa. } \\
\text { iii) Manter em foco os problemas é fundamental para compreender porque este, e não } \\
\text { aquele, caminho foi tomado em determinado momento histórico. Esta talvez seja a maior }\end{array}$ \\
\hline
\end{tabular}




\begin{tabular}{|c|c|}
\hline & $\begin{array}{l}\text { virtude do curso. } \\
\text { iv) Tomar experimentos como ponto de partida desperta muito mais a curiosidade do } \\
\text { que qualquer forma "teórica" de começar. Participar da execução de um experimento } \\
\text { sob a orientação de um bom professor é algo que me parece extremamente valioso, até } \\
\text { mesmo quando as coisas não saíam como planejado. Na verdade dá para aprender mais } \\
\text { ainda quando é necessário reajustar os equipamentos. } \\
\text { v) O material entregue a nós estudantes ao longo do curso é um convite a não acumular } \\
\text { conteúdos. São ótimos roteiros de estudo e têm servido também a posteriori. O espaço } \\
\text { em branco nas apostilas é um convite à escrita, ou melhor, à construção do próprio } \\
\text { entendimento. } \\
\text { vi) As referências bibliográficas são ótimas leituras. Além de que fogem um pouco da } \\
\text { rotina entediante dos livros-texto comuns. } \\
\text { Quanto aos aspectos negativos (item b): } \\
\text { R: } \\
\text { Honestamente, não tenho objeç̃es. Mas para não deixar esta parte em branco, um } \\
\text { aspecto negativo é o fato de o curso não ser obrigatório para o bacharelado. É uma pena. } \\
\text { Quanto à autoavaliação (item c) - Considera que aprendeu o conteúdo do curso? } \\
\text { Explique: } \\
\text { R: } \\
\text { Sim, porque percebi que na realidade eu não compreendia aquilo que julgava saber por } \\
\text { ter feito outras disciplinas. Tive tempo, espaço e incentivo para desconstruir e } \\
\text { reconstruir ideias, impressões e até mesmo intuições a respeito do conteúdo estudado. } \\
\text { Quanto às sugestões para melhorar o curso (item d): } \\
\text { R: } \\
\text { i) Mais um pouco (só um pouco mesmo) de matemática nos exercícios e na exposição. } \\
\text { Vou justificar: combinar o conhecimento formal com o dinamismo do curso pode jogar } \\
\text { uma luz sobre o próprio aspecto formal, que é, sem dúvida, uma fonte de dores de } \\
\text { cabeça da maioria dos meus colegas. } \\
\text { Para ser mais exato: seria como usar cores para escrever aquelas equações que sempre } \\
\text { estiveram em preto-e-branco. } \\
\text { R: } \\
\text { ii) Dar um peso maior àqueles questionários que são entregues de tempos em tempos } \\
\text { para "forçar" a estudar um pouco mais e "tomar posse" das discussões de uma forma } \\
\text { mais concreta. }\end{array}$ \\
\hline Aluno 2 & $\begin{array}{l}\text { Quanto aos aspectos positivos (item } \boldsymbol{a} \text { ): } \\
\text { R: } \\
\text { Enfoque histórico que proporciona a compreensão temporal dos acontecimentos } \\
\text { descobertas e demonstrações; } \\
\text { A utilização da matemática dando suporte e efetividade aos fenômenos estudados em } \\
\text { sala; } \\
\text { Aproveitamento e organização do horário da aula, torna-se perceptível que houve uma }\end{array}$ \\
\hline
\end{tabular}




\begin{tabular}{|c|c|}
\hline & $\begin{array}{l}\text { preparação antecipada; } \\
\text { A avaliação ao nível de abordagem dos assuntos vistos em sala; } \\
\text { A dedicação do docente às aulas, a fim de que os alunos construam uma visão crítica dos } \\
\text { temas abordados; } \\
\text { O planejamento do curso. } \\
\text { Quanto aos aspectos negativos (item b): } \\
\text { R: } \\
\text { O único aspecto negativo do curso foi a heterogeneidade da turma, alunos em diferentes } \\
\text { fases do curso, que dificultou a compreensão de algumas abordagens matemáticas, } \\
\text { necessárias para a compreensão mais sólida dos fenômenos físicos. } \\
\text { Quanto à autoavaliação (item c) - Considera que aprendeu o conteúdo do curso? } \\
\text { Explique: } \\
\text { R: } \\
\text { Considero a estrutura do curso, apostilas, equipamentos, suporte matemático, } \\
\text { bibliografias configuram sem dúvidas um excelente aprendizado. Considero-me apto a } \\
\text { qualquer debate que envolva assuntos do curso relacionados aos vistos na disciplina. } \\
\text { Quanto às sugestões para melhorar o curso (item } d \text { ): } \\
\text { R: } \\
\text { Apenas uma sugestão: regular mais o tempo de discussões durante a aula, pois em } \\
\text { algumas perdemos um pouco o foco do tema para ser abordado em determinada aula. }\end{array}$ \\
\hline Aluno 3 & $\begin{array}{l}\text { Quanto aos aspectos positivos (item } \boldsymbol{a} \text { ): } \\
\text { R: } \\
\text { - Aulas discursivas, dando oportunidade ao aluno de questionar sobre seus } \\
\text { conhecimentos prévios e esclarecer dúvidas em vários níveis. } \\
\text { - Oportunidade única no curso de aprender o contexto histórico associado à visão } \\
\text { experimental dos problemas de Óptica eletromagnética e da física moderna. } \\
\text { Quanto aos aspectos negativos (item b): } \\
\text { R: } \\
\text { - Tempo curto; } \\
\text { - Acho que pode ter faltado alguns momentos de fechamento (conclusões) das } \\
\text { discussões em torno dos experimentos realizados, talvez por falta de tempo; } \\
\text { Quanto à autoavaliação (item c) - Considera que aprendeu o conteúdo do curso? } \\
\text { Explique: } \\
\text { R: } \\
\text { - Creio ter aprendido boa parte do conteúdo estudado. O que não consegui aprender, saí } \\
\text { com base e estímulo para estudar mais os assuntos; } \\
\text { Quanto às sugestões para melhorar o curso (item } d \text { ): } \\
\text { R: } \\
\text { - Reservar mais tempo para discutir os experimentos. }\end{array}$ \\
\hline
\end{tabular}




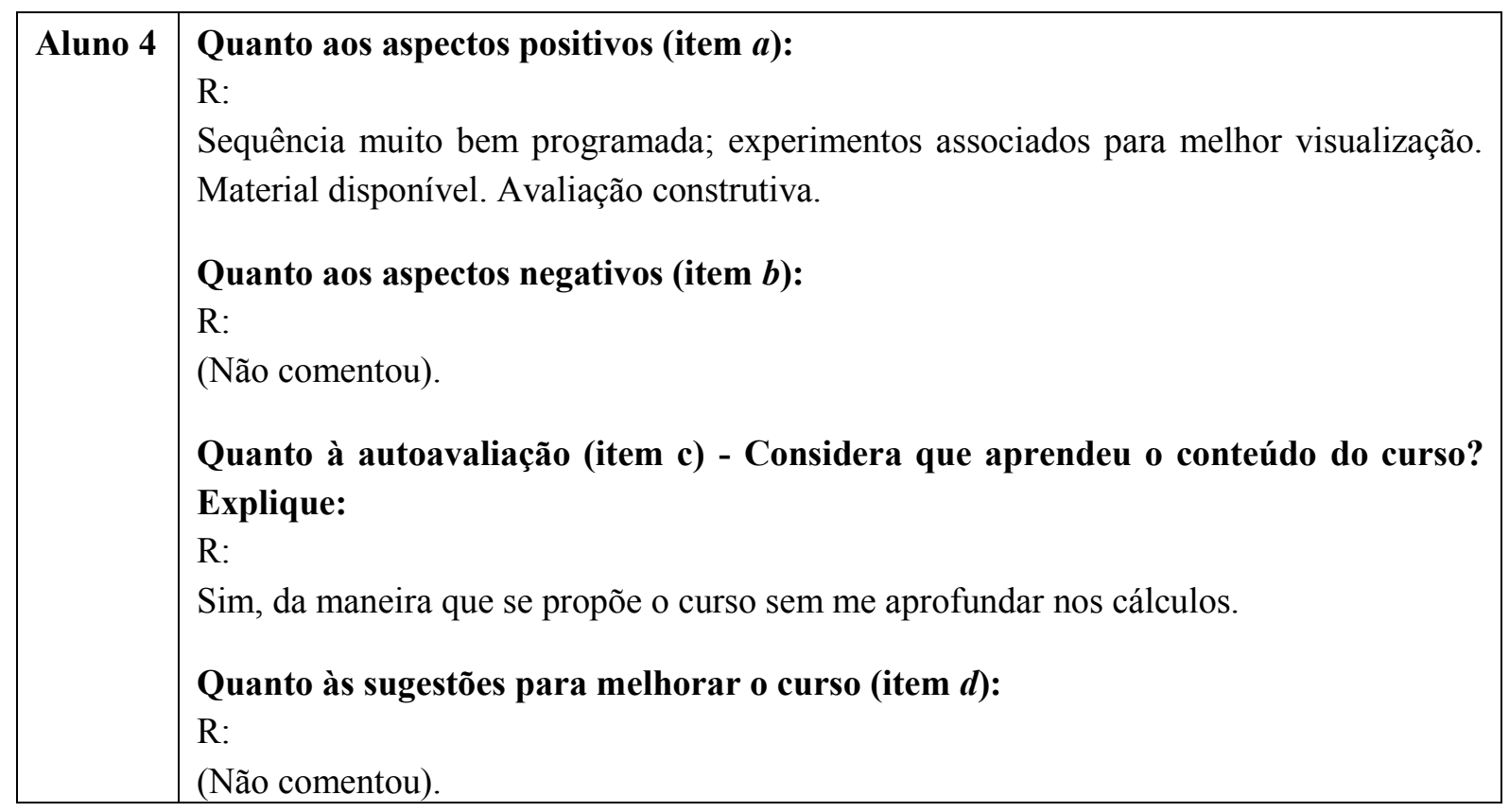

Fonte: ROCHA (2014).

Como se vê, as opiniões avaliativas dos discentes foram de aprovação, com poucas restrições. Houve referência positiva à orientação geral dada no curso, que mantinha em constante evidência os objetivos a serem alcançados ao seu final. Para um dos alunos, em consonância com o exposto no início da subseção IV.2, deste artigo, a maior virtude do curso talvez tenha sido manter em foco os problemas mais gerais da óptica, constantemente retomados ao longo do curso a partir dos diversos fenômenos básicos estudados. A maioria dos alunos, refletindo o modo como o curso foi estruturado, apresentado no primeiro parágrafo da sessão II, destacou o enfoque histórico utilizado, tendo um deles considerado, explicitamente, como uma oportunidade para aprender o contexto histórico associado à visão experimental dos problemas de óptica eletromagnética e da física moderna. Todos os alunos fizeram referência positiva à parte experimental utilizada no curso (usando termos como experimentos, fenômenos, equipamentos, demonstrações etc.). Para um dos alunos, em consonância com o que foi apresentado no segundo parágrafo da subseção IV.1, tomar experimentos como ponto de partida desperta mais a curiosidade do que qualquer forma "teórica" de começar uma aula, sendo que participar da execução de um experimento, sob a orientação de um professor, foi algo que pareceu valioso. Todos fizeram referência positiva também à utilização (parcimoniosa, conforme indicado na ementa - Fig. 1.a) da matemática como suporte ao estudo dos fenômenos apresentados. Além disso, foi citado o desenvolvimento gradativo dos temas, com uma sequência muito bem programada, permitindo um melhor entendimento dos mesmos, com discussões em sala, dando oportunidade ao aluno de questionar sobre seus conhecimentos prévios e esclarecer dúvidas em vários níveis. Positivas também foram consideradas a entrega do material didático ao longo do curso, otimizando o tempo de aula, e a avaliação feita ao nível do que foi 
apresentado em sala. Por outro lado, foram relacionados como aspectos negativos a heterogeneidade da turma e o pouco tempo para discutir os experimentos. Como sugestão, foi citada a necessidade de acrescentar ao curso um pouco mais de matemática e ajustar melhor o tempo das discussões em sala de aula. O curso foi, portanto, bem avaliado por esses alunos.

\section{V.2 Opiniões avaliativas dos discentes obtidas através da metodologia da história oral}

Nesta subseção, em razão dos objetivos deste artigo, serão apresentadas as opiniões avaliativas de discentes apenas sobre a abordagem utilizada na disciplina Física Básica IV, obtidas através da metodologia da história oral. Das nove entrevistas realizadas com os discentes de semestres diversos ${ }^{12}$, serão destacadas, inicialmente, duas delas, uma com avaliação favorável e outra com ponderações críticas importantes a respeito do oferecimento dessas disciplinas. Depois serão apresentadas as opiniões dos demais ex-alunos. Vale ainda esclarecer que, como as entrevistas foram realizadas num contexto de análise da repercussão das inovações trazidas pelas quatro Físicas Básicas, e não só por uma delas, os alunos poderão, eventualmente, fazer referências também a outras Físicas Básicas, o que, entretanto, não prejudicará o entendimento do que está sendo discutido. Segue a síntese das opiniões avaliativas dos discentes a respeito da abordagem utilizada.

Para o ex-aluno DSS (semestre 2008.2), os aspectos históricos e fenomenológicos foram os que lhe chamaram mais atenção no curso. Afirma que a abordagem utilizada pelo professor nesse curso foi excelente e que essa foi a melhor das Físicas Básicas que fez. Considera que todas foram importantes, mas a Física Básica IV, por tratar questões que envolvem a natureza da luz, foi a que mais lhe despertou interesse. Considera que fazer uma graduação em Licenciatura de Física sem passar por disciplinas como Física Básica III e IV é um erro, porque acredita que a vivência e as discussões realizadas, não vão aparecer em outro lugar, em outro momento. Ele finaliza reafirmando que as Físicas Básicas III e IV foram fundamentais para sua formação, porque o estimularam a entender a Física como construção humana, a entender a Física como construção cultural, a entender que são pessoas de carne e osso que fazem a ciência. Na visão do ex-aluno MPC (2006.2), a abordagem utilizada pelo professor, na apresentação dos assuntos de óptica e física moderna, também foi boa e se considera um aluno de sorte por ter seu professor entendido a proposta ou concepção da disciplina. Diz que gostava dos experimentos realizados em laboratório, mas não sabe se isto era próprio da disciplina ou se era devido ao professor que a estava ministrando. Afirma que a parte de física moderna foi a que mais lhe despertou interesse por ser um conteúdo, segundo ele, pouco estudado no Curso de Física, Licenciatura, noturno. Apesar de considerar a proposta das Físicas Básicas "bastante válida" e considerar que essas disciplinas foram importantes para a sua formação, ressalta que os cursos ministrados poderão ser totalmente inúteis se a concepção e abordagem dessas disciplinas não forem bem compreendidas pelos

\footnotetext{
12 Foram entrevistados nove ex-alunos da Licenciatura, noturno, escolhidos de forma a estarem distribuídos nos mais variados anos (12 anos): 2001, 2002, 2003, 2005, 2006, 2007, 2008, 2009, 2010 e 2011.
} 
professores. Diz que, no seu caso, as Físicas Básicas foram muito proveitosas, mas que nem todos os colegas tiveram a mesma sorte e, às vezes, essas disciplinas podem ser totalmente inúteis. O ex-aluno FLAP (2001.2), por sua vez, primeiro esclarece que a disciplina Física Básica IV, no semestre em que cursou, foi ministrada por dois professores, em parceria, e a abordagem utilizada na parte de óptica não foi a mesma utilizada em física moderna. $\mathrm{Na}$ primeira, o professor explorava as questões fenomenológicas e históricas, mas, em física moderna, foi utilizado um trabalho de tese já experimentado em outra universidade, e esse material didático não era de textos históricos ou algo que pretendesse fazer uma abordagem histórica. Para o ex-aluno FLAP, o docente de cada uma das Físicas Básicas deveria ser alguém que, "dentro da sua vida acadêmica, estudou, pesquisou ou tem interesse em História e Filosofia da Ciência". O ex-aluno AMCN (2002.2) não fala especificamente sobre a abordagem utilizada pelo professor em Física Básica IV, mas lembra que óptica foi estudada em profundidade e não se recorda de ter visto física moderna nessa disciplina. Afirma que é fundamental para o licenciando cursar as Físicas Básicas antes das Físicas Gerais e Experimentais, ou em paralelo. O ex-aluno ASB (2006.1) também não falou especificamente da abordagem utilizada em Física Básica IV. Declara lembrar-se, entretanto, de ter estudado reflexão, refração, cores, polarização, e outros temas, mas não conseguiu lembrar-se de ter estudado tópicos de física moderna, ficando em dúvida se tinha visto o efeito fotoelétrico em Física Básica IV ou em Estrutura da Matéria. Ele considera interessante o fato da Física Básica I vir primeiro do que a Física Geral e Experimental I, e afirma que é necessário igualar os currículos das licenciaturas, diurno e noturno, modificando o da licenciatura, diurno, para torná-lo igual ao currículo da licenciatura, noturno [Isso foi feito em 2016]. Na visão da exaluna IAB (2011.2), a abordagem utilizada pelo professor foi semelhante àquela utilizada em Física Básica III. No seu caso, foi o mesmo professor e o método era parecido com o da referida disciplina, que consistia em estar o tempo todo questionando, fazendo o aluno pensar sobre o que já havia ouvido antes, mas que nunca tinha se aprofundado e pensado. Ela vai adiante dizendo que se a parte prática das Físicas Gerais e Experimentais fosse mais eficiente e o aluno aprendesse realmente com o laboratório, talvez a parte prática de Física Básica III e IV pudesse ser, não substituída, porque a considera fundamental, mas pudesse ser menos detalhada, ocupando um tempo menor do que o da teoria, de forma a haver mais espaço para outros questionamentos e debates em torno de determinadas questões. Afirma ainda que foram os assuntos relativos à física moderna os que lhe despertaram mais interesse. Para ela, as discussões sobre o início da mecânica quântica... Planck, Einstein, os experimentos dessa época, discutidos em sala de aula, foram muito interessantes. Diz que se matriculou em Física Básica III e IV, porque, entre outras razões, achou deficientes os cursos de Física Geral e Experimental. A ex-aluna IAB finaliza suas declarações, afirmando que ou se melhora as Físicas Gerais e Experimentais, do Bacharelado, para que estas supram o conteúdo das Físicas Básicas, ou se incorpora estas disciplinas ao curso de Bacharelado ${ }^{13}$. Para o ex-aluno CSS,

13 Em 1988, dez anos antes da criação das Físicas Básicas, foi feita uma tentativa de aperfeiçoamento das Físicas 
(2010.2) também foi boa a abordagem utilizada pelo professor. Esclarece que já tinha feito Física Geral e Experimental IV, quando cursou Física Básica IV e diz que esse foi um momento de consolidar os conteúdos voltados à questão das ondas eletromagnéticas. Afirma que alguns conteúdos de Física Básica IV lhe chamaram muita atenção, a exemplo de alguns cálculos envolvendo o conceito de probabilidade. Para CSS, as Físicas Básicas, de certo modo, já são obrigatórias para os estudantes do curso noturno, pela pouca oferta de disciplinas optativas no turno da noite, mas, mesmo assim, devem se tornar formalmente obrigatórias. Salienta, entretanto, que estas disciplinas devem ser ministradas por professores que estejam dispostos a cumprir a proposta que motivou sua criação. Para MHR (2010.2), a abordagem utilizada também foi muito boa. Diz ter gostado bastante da metodologia em que a aula começava com o experimento e o professor deixava a pergunta no ar para o aluno refletir, debater com os colegas e chegar a uma conclusão, um procedimento que era apoiado pelo material didático distribuído pelo professor. Afirma também que gostou da sequência dos assuntos apresentados, pois os tópicos se complementavam e os conceitos já compreendidos ajudavam a entender os seguintes, formando uma cadeia, mostrando que os eventos estavam interligados. Destaca ter gostado da discussão que tratava do confronto das ideias da luz como onda e como partícula, inclusive a discussão do porquê um fenômeno típico, como o da dupla fenda, funcionava. Acrescenta ainda que sentiu a necessidade de uma Física Básica relacionada com a Estrutura da Matéria, para cumprir um papel análogo àquele que as Físicas Básicas cumprem com relação às Físicas Gerais e Experimentais. Finaliza dizendo que Física Básica IV complementou significativamente o que viu em Física Geral e Experimental IV, dizendo ter começado, a partir delas, a ver significado nas equações e nos problemas que resolvia, além de ter despertado para a parte experimental e da História da Ciência. Dos nove ex-alunos, LHSS foi o único que não tinha feito Física Básica IV e, por esta razão, não deu sua opinião sobre a disciplina, afirmando o seu desejo de cursá-la.

Com base nos depoimentos apresentados, podemos dizer que a abordagem utilizada mereceu aprovação da maioria dos alunos entrevistados, especialmente daqueles que a cursaram nos últimos anos em que foi oferecida, o que está coerente com o contínuo processo de ajuste por que passou essa disciplina, particularmente, a parte relativa à física moderna, conforme referido, por exemplo, no penúltimo parágrafo da subseção IV.2. Um dos pontos valorizados foi o da utilização de experimentos como motivadores das discussões históricomatemático-conceituais, que se seguiam a tais experimentos. Um dos entrevistados, em consonância com o que foi exposto no segundo parágrafo da subseção IV.1, afirma ter gostado bastante da metodologia em que a aula começava com o experimento e o professor deixava a pergunta no ar para o aluno refletir, debater com os colegas e chegar a uma

Gerais e Experimentais, para alunos de física, ampliando-se a carga horária de cada uma delas, de 90 para 150 horas semestrais. Essa iniciativa não produziu, entretanto, os resultados desejados, levando ao desdobramento, em 1998, dessas disciplinas em dois novos conjuntos: o das Físicas Gerais e Experimentais, com 90 horas semestrais (atualmente 102), cada uma, e o das Físicas Básicas, com carga horária de 60 horas semestrais (atualmente 68), cada uma. 
conclusão, um procedimento que era apoiado pelo material didático distribuído pelo professor. Um outro relata que a metodologia utilizada pelo professor consistia em estar o tempo todo questionando, fazendo o aluno pensar sobre o que já havia ouvido antes, mas que nunca tinha se aprofundado, enquanto um terceiro diz ter gostado dos experimentos, mas que não sabe se isso era próprio da disciplina ou se era devido ao professor que a estava ministrando. Outro discente relembrou ainda que, no semestre em que cursou essa disciplina (2001.2), a abordagem utilizada na parte de óptica não foi a mesma utilizada em física moderna, o que, como foi dito no segundo parágrafo da seção II, por exemplo, ocorreu apenas nos dois primeiros semestres do período analisado. No que diz respeito, especificamente ao conteúdo da física moderna, dois dos entrevistados (dos semestres 2002.2 e 2006.1) não se lembraram, perfeitamente, que estudaram física moderna no curso, outros, entretanto, afirmam que a parte de física moderna foi a que mais despertou interesse, em razão das discussões sobre o início da mecânica quântica, ou por ser um conteúdo pouco estudado no Curso de Física, Licenciatura, noturno. Com relação à relevância, vários entrevistados consideraram essa dessa disciplina importante para a sua formação, chegando um deles a afirmar que não só a Física Básica IV, mas também a Física Básica III foram fundamentais para sua formação, porque o estimularam a entender a Física como construção humana, a entender a Física como construção cultural, e a entender que são pessoas de carne e osso que fazem a ciência. Houve, entretanto, alunos que fizeram ponderações importantes, inclusive aquela que ressalta que os cursos ministrados nas Físicas Básicas poderão ser totalmente inúteis se a concepção e abordagem dessas disciplinas não forem bem compreendidas pelos professores, e também a que sugere que essas disciplinas devem ser ministradas por professores que estejam dispostos a cumprir a proposta que motivou a sua criação. Essas ponderações dos alunos certamente remetem a uma das principais dificuldades enfrentadas por essas disciplinas, ao longo do período em que foram oferecidas, qual seja, a da existência de lacunas na formação de docentes de nível superior, como reflexo do modelo tradicional do ensino universitário básico, para ministrar disciplinas dessa natureza. Ver também Rocha (2014, p. 171).

Ao finalizar esta subseção sobre a receptividade dos alunos à abordagem utilizada nessa disciplina, consideramos ser útil apresentar ainda o desempenho (aprovação reprovação) dos alunos matriculados em Física Básica IV, nos 12 primeiros anos em que essa disciplina foi ministrada, avaliado através de verificações individuais escritas e de participação no curso: De um total de 183 alunos matriculados, $69 \%$ foram aprovados, 13\% foram reprovados por conceito ou por média e $18 \%$ foram reprovados por frequência ou trancaram a disciplina (IFUFBA, 2011).

\section{V.3 Opinião avaliativa do docente obtida através da metodologia da história oral}

Para completar a avaliação da abordagem utilizada na disciplina Física Básica IV (atual Conceitos de Física $D$ ), serão apresentadas, a seguir, a opinião avaliativa do docente 
que a ministrou, em parceria com um colega, nos primeiros semestres em que essa disciplina foi oferecida.

Ao falar sobre sua experiência em ministrar a citada disciplina, nos semestres 2000.2 e 2001.2, o docente OFJ declara que a impressão que tem é a de que foi uma experiência positiva, apesar de não ter feito uma avaliação sistemática da mesma. Recorda-se que, em um desses semestres citados, foi feita uma experiência didática com um material que a professora Ileana Greca tinha usado no Rio Grande do Sul e, na sua visão, a percepção dos alunos foi muito positiva, especialmente porque incluía mecânica quântica como parte de seu conteúdo. Reafirma, entretanto, que foi uma experiência que não pôde avaliar melhor, e admite que, na continuidade, certamente precisaria de inovações e ajustes, considerando-a, por isso, uma experiência limitada. De qualquer forma, lembra que foi uma experiência positiva. Para o professor OFJ, o aluno precisa desde muito cedo ter contato com a física moderna e essa sua opinião decorre de sua própria experiência como estudante. Ele esclarece que só muito depois do início do oferecimento das Físicas Básicas é que foi iniciada uma avaliação sistemática da disciplina Física Básica I, por Elder Sales Teixeira, como parte da sua tese, e lembra que fez uma avaliação na primeira ou na segunda turma de Física Básica I, mas que, infelizmente, nunca teve fôlego para dar continuidade a este trabalho. Garante, entretanto, que as referências que tinha do que os alunos falavam, do que os alunos comentavam, foram sempre de uma experiência muito positiva.

Ao falar das vantagens de uma abordagem contextual ou histórico-conceitual utilizada nas Físicas Básicas, pelo menos nas Físicas Básicas I, III e IV, o professor OFJ esclarece que não é a forma do currículo da Licenciatura, noturno, contemplando um projeto de quatro Físicas Básicas, nas quais está garantido um espaço para adoção de uma abordagem contextual, que é o essencial. Para ele, o essencial é que seja garantida a presença de uma abordagem contextual na formação do Licenciado em Física. Ele relaciona como vantagens da abordagem contextual o fato de que esta motiva mais os alunos, situa os alunos num horizonte cultural mais vasto e ajuda a compreender melhor certos conceitos que o ensino tradicional torna mais opacos. Além de defender enfaticamente a abordagem contextual, o professor OFJ afirma que é também necessário acelerar o contato dos alunos, os futuros licenciados, com a Física do século XX, algo que só temos a ganhar, porque isto atrai o aluno, prende o aluno. Finalmente, ao comentar a recente reformulação curricular aprovada pelo Instituto de Física, em 2013 [e aprovada pelos órgãos superiores da UFBA, em 2015], na qual as Físicas Básicas (agora denominadas Conceitos de Física $A, B, C$ e $D$, tendo apenas a $D$ como optativa) foram incorporadas ao currículo do curso diurno, além de permanecerem no curso noturno, o professor OFJ diz que, em princípio, considera tal reformulação positiva, aparentemente positiva, e esclarece:

Mas por que eu estou dizendo em princípio e aparentemente? É que da minha experiência e da minha vivência na universidade, muitas vezes são poucas as disciplinas que a ementa e a bibliografia dizem o que é. Boa parte [...] são 
disciplinas que vão depender sempre do que é que vai ser ensinado. Então, eu acho que pode ser positiva, dependendo do que vai ser ensinado, quem vai ensinar e de maneira muito clara, se for ... se debaixo de Conceitos de Física tiver abordagem contextual, eu acho ótimo e excelente. Se for outra coisa, não sei, vamos ver. É uma nova experiência, porque pode ser outra coisa, pode ser alguém que vá, por exemplo, trabalhar só com computadores, com simulações, hipoteticamente é outra, não quer dizer que seja negativa, eu quero dizer que é outra experiência (ROCHA, 2014, p. 222).

Como se vê, o depoimento do docente sobre a abordagem utilizada na disciplina complementa a avaliação feita pelos próprios discentes, ao defender esse tipo de abordagem. Apesar de o professor OFJ não utilizar experimentos na parte do curso pela qual ficou responsável (parte de física moderna), sua avaliação é que sua experiência de ensino foi positiva, o que não contaria com a concordância plena de pelo menos um dos discentes.

Quanto à forma do currículo da licenciatura, contemplando um projeto de quatro físicas básicas, nas quais está garantido um espaço para a adoção de uma abordagem contextual, o referido docente considera que não é esse formato que é essencial, e sim que seja garantida a presença de uma abordagem contextual na formação do Licenciado em Física. Sobre o formato Físicas Básicas no currículo da Licenciatura, ver também Rocha (2014, p. 271).

\section{Considerações finais}

A análise histórica dessa experiência de ensino, envolvendo a disciplina Conceitos de Física $D$, anteriormente denominada Física Básica IV, revelou as principais dificuldades encontradas para implantar e desenvolver essa disciplina e como as mesmas foram enfrentadas pelos professores, ao longo do tempo. Mostrou também como o seu conteúdo programático foi efetivamente trabalhado em sala de aula, isto é, como as atividades foram realizadas, qual o material usado e como os alunos interagiram com esse material, tendo sido apresentada também a visão dos alunos e do docente que a ministrou em parceria com um colega sobre a abordagem utilizada na mencionada disciplina.

Tal análise mostrou ainda que a mencionada disciplina se constitui em um exemplo de incorporação da história da ciência ao ensino de ciências, e que disciplinas como essa podem preencher lacunas do ensino da física universitária básica, deixadas pelas tradicionais Físicas Gerais e Experimentais, o que ficou evidenciado, especialmente, nas manifestações dos alunos ao exporem suas opiniões avaliativas referentes ao curso ministrado.

\section{Referências Bibliográficas}

BASSAlo, J. M. F.; CATTANI, M. S. D. Elementos de Física Matemática. São Paulo: Editora Livraria da Física, 2011. v. 2. 
CALvacAnte, M. A.; HAAG, R. Revista Brasileira de Ensino de Física, v. 27, n. 3, 2005.

DESCARTES, R. Refraction of Light. Extrato do La Dioptrique, publicado em 1637 como um suplemento ao Discours de la Methode. In: F.W. Magie, A source book in Physics. Cambridge, Massachsetts: Harvard University Press, 1969.

HALLIDAY, D; RESNICK, R. Física. Rio de Janeiro: Livros Técnicos e Científicos Editora, 1984.

HECHT, E. Óptica. Lisboa: Fundação Calouste Gulbenkian, 1991.

HUYGENS, C. Tratado sobre a Luz. In. Cadernos de História e Filosofia da Ciência, Suplemento 4/1986.

IFUFBA - INSTITUTO DE FÍSICA DA UFBA - Colegiado de Graduação em Física. Cadernetas de Física Básica IV, de 2000 a 2011.

MEIHY, J. C. S. B.; ROBEIRO S. L. S. Guia prático de história oral. São Paulo: Editora Contexto, 2011.

NEWTON, I. Óptica, São Paulo: Edusp, 1996.

OliVEIRA FilHO K. de S.; SARAIVA, M. de F. O. Astronomia e Astrofísica, 2014. Disponível em: <http://astro.if.ufrgs.br/livro.pdf>. Acesso em: 21 jun. 2020.

OZAMIZ, M. de G. Aventuras Matemáticas. Lisboa: Editora Gradiva, 1986.

ROCHA, J. F. M. Origem e Evolução do Curso de Física, Licenciatura, noturno, da Universidade Federal da Bahia - o caso das disciplinas Física Básica III e IV. 2014. 711 p. Tese (Doutorado) - Programa de Pós-Graduação em Ensino, Filosofia e História das Ciências, Universidade Federal da Bahia, Salvador. Disponível em:

$<$ https://ppgefhc.ufba.br/sites/ppgefhc.ufba.br/files/tese_final_0.pdf $>$. Acesso em: 23 nov. 2018.

ROCHA, J. F. M. et al. Origens e Evolução das Ideias da Física. 2. ed. Salvador: EDUFBA, 2015.

ROCHA, J. F. M. Caderno Brasileiro de Ensino de Física, v. 33, n. 1, 2016 a. 
ROCHA, J. F. M. Caderno Brasileiro de Ensino de Física, v. 33, n. 2, 2016 b.

ROEMER, O. The velocity of Light. In: MAGIE, F. W. A source book in Physics. Cambridge, Massachsetts: Harvard University Press, 1969.

ROSMORDUC, J. De Tales a Einstein. Lisboa: Editorial Caminho, 1983.

SCHRÖDINGER, E. Collected Papers on Wave Mechanics. Providence, Rhode Island: AMS Chelsea Publishing, American Mathematical Society, 1982.

TIPLER, P. A. Física Moderna. Rio de Janeiro: Editora Guanabara Dois, 1981. 